\title{
Influencers on Thyroid Cancer Onset: Molecular Genetic Basis
}

\author{
Berta Luzón-Toro ${ }^{1,2}$, Raquel María Fernández ${ }^{1,2}$, Leticia Villalba-Benito ${ }^{1,2}$, Ana Torroglosa 1,2, \\ Guillermo Antiñolo 1,2 and Salud Borrego 1,2,* \\ 1 Department of Maternofetal Medicine, Genetics and Reproduction, Institute of Biomedicine of Seville (IBIS), \\ University Hospital Virgen del Rocío/CSIC/University of Seville, 41013 Seville, Spain; \\ berta.luzon@ciberer.es (B.L.-T.); raquelm.fernandez@juntadeandalucia.es (R.M.F.); \\ leticia.villalba.benito@hotmail.es (L.V.-B.); ana.torroglosa@juntadeandalucia.es (A.T.); \\ guillermo.antinolo.sspa@juntadeandalucia.es (G.A.) \\ 2 Centre for Biomedical Network Research on Rare Diseases (CIBERER), 41013 Seville, Spain \\ * Correspondence: salud.borrego.sspa@juntadeandalucia.es; Tel.: +34-955-012641
}

Received: 3 September 2019; Accepted: 6 November 2019; Published: 8 November 2019

check for updates

\begin{abstract}
Thyroid cancer, a cancerous tumor or growth located within the thyroid gland, is the most common endocrine cancer. It is one of the few cancers whereby incidence rates have increased in recent years. It occurs in all age groups, from children through to seniors. Most studies are focused on dissecting its genetic basis, since our current knowledge of the genetic background of the different forms of thyroid cancer is far from complete, which poses a challenge for diagnosis and prognosis of the disease. In this review, we describe prevailing advances and update our understanding of the molecular genetics of thyroid cancer, focusing on the main genes related with the pathology, including the different noncoding RNAs associated with the disease.
\end{abstract}

Keywords: thyroid cancer; genetics; epigenetics; mutation

\section{Introduction}

Thyroid cancer is the most common endocrine cancer, with an increasing overall incidence in recent decades of about two fold in the last 25 years and accounting for $2 \%$ of all cancers [1]. Thyroid cancer is the sixth most common cancer in women, who are three times more likely to have thyroid cancer than men. About $2 \%$ of cases occur in children and teens. Overall, the 5-year survival rate of thyroid cancer is $98 \%$. However, survival rates depend on many factors, such as the specific type of thyroid cancer and stage of disease [2]

Several types and histological subtypes can be found depending on the cells from which the tumor derives, and each one presents different characteristics and prognoses. Non-medullary thyroid cancer (NMTC) originates from follicular cells and is responsible for $\sim 95 \%$ of all the cases. At the same time, NMTC is divided into four groups (also known as well differentiated thyroid cancer): (1) papillary thyroid cancer (PTC), which represents more than 85\% of cases, (2) follicular thyroid cancer (FTC; $10 \%$ of total cases), (3) poorly differentiated thyroid cancer (PDTC, which accounts for only 1-15\% of all thyroid cancers), constitutes a more aggressive follicular-derived thyroid cancer than differentiated thyroid cancer (PTC and FTC), and (4) anaplastic cancer (ATC) $(<1 \%)$ [3].

Of the total number of cases, $10 \%$ of NMTCs occur during the first two decades of life [4]. Around 5\% present as familial forms and the remaining 95\% are sporadic. Analysis (genome-wide association study or genome-wide linkage analysis) has led to the identification of some genes associated with non-syndromic familial forms, although additional populations are needed for further validations [5-9]. In either case, the studies carried out to date are quite inconclusive, and thus new approaches should be carried out for the identification of new loci associated with FNMTC. 
In addition, only $\sim 5 \%$ of cases of thyroid cancer are derived from parafollicular cells and this type is named medullary thyroid cancer (MTC) $[4,10]$. About $75 \%$ of all MTCs are believed to be sporadic (sMTC), and the remaining $25 \%$ correspond to inherited cancer syndromes known as multiple endocrine neoplasia type 2 (MEN2). MEN2 includes three clinically differentiable types: MEN2A (OMIM \#171400), MEN2B (OMIM \#162300), and FMTC (OMIM \#155240; which may be a variant of MEN 2A) [11,12]. FNMTC is a rare form of thyroid cancer (only 3-9\% of all cases). Moreover, just $5 \%$ of the family forms are included in specific syndromes: Cowden (OMIM \#158350), Gardner (OMIM \#175100), Werner (OMIM \#277700), Li-Fraumeni (OMIM \#151623), McCune-Albright (OMIM \#174800), Carney complex (OMIM \#160980), or DICER 1 (OMIM\#138800) syndromes [5,6]). This review summarizes the current knowledge about molecular bases of thyroid cancer: from genes to ncRNAs, to provide the reader an overview of the main genetic and epigenetic factors that can influence the develop of thyroid cancer.

\section{Molecular Genetics of Thyroid Cancer}

Alterations on some genes and pathways have been described to be associated with the different forms of thyroid cancer. The most relevant are summarized in the current review (Figure 1). Thyroid tumorigenesis and progression are closely linked to somatic point mutations on BRAF (B-rapidly accelerated fibrosarcoma), RAS, RET, and NTRK1/3 genes that promote the activation of mitogen-activated protein kinase (MAPK) and phosphoinositide 3-kinase (PI3K) signaling pathways [13,14]. Interestingly, there is a strong relationship between the oncogenic genotype and histopathologic phenotype, mutations in BRAF, PAX8, and PPARG genes being common in FTC and RAS mutations either in FTC and PTC (follicular variant, fvPTC) [15-19]. The global analysis of genomic variants, gene and miRNA expression, aberrant methylation, and proteomic profiles unraveled that mutations in BRAF and RAS, together with RET-PTC fusions, are the most common genetic alterations in both FTC and PTC.

It is worth mentioning The Cancer Genome Atlas (TCGA) project outcomes, where a comprehensive and multiplatform approach to analyze multidimensional molecular data of 496 PTCs (excluding both poorly and undifferentiated carcinomas to compile all tumor-initiating alterations) was performed. Such a cohort led to classification into molecular subtypes (including tumor cluster, histology, genotype, signaling, and risk assessment) to associate them with clinically relevant parameters and improve the management of patients. They mainly distinguish two types of PTC tumors: PTCs with RAS mutations (RL-PTCs) and BRAFV600E-driven tumors (BVL-PTCs). Both are basically different in their genomic, epigenomic, and proteomic profiles, which is in concordance with their histological differences [20].

\section{The RET Proto-Oncogene Role}

In 1993 RET proto-oncogene was demonstrated to be the causative event for MTC [21]. Since then, several mutations have been described in MEN2 series. Thus, the RET genetic screening is a crucial diagnostic and prognostic procedure for MTC [22].

\subsection{Somatic RET Mutations}

\subsubsection{RET Gene Rearrangements}

The Rearranged During Transfection (RET) gene encodes a single transmembrane receptor, which is a tyrosine kinase implicated in the cellular signaling of members of the glial derived neurotrophic factors family [23].

In PTC, RET rearrangements (RET-PTC) seem to be an early event in carcinogenesis, with $10-20 \%$ of RET fusions being detected in PTC patients. RET-PTC fusions used to be associated with sporadic and radiation-induced PTC [24,25]. In addition, coiled-coil domain containing 6-RET rearrangements are also commonly found in this type of tumor [26,27]. The presence or higher expression of a RET fusion protein has been linked to regional invasion and lymph node metastasis [28]. 


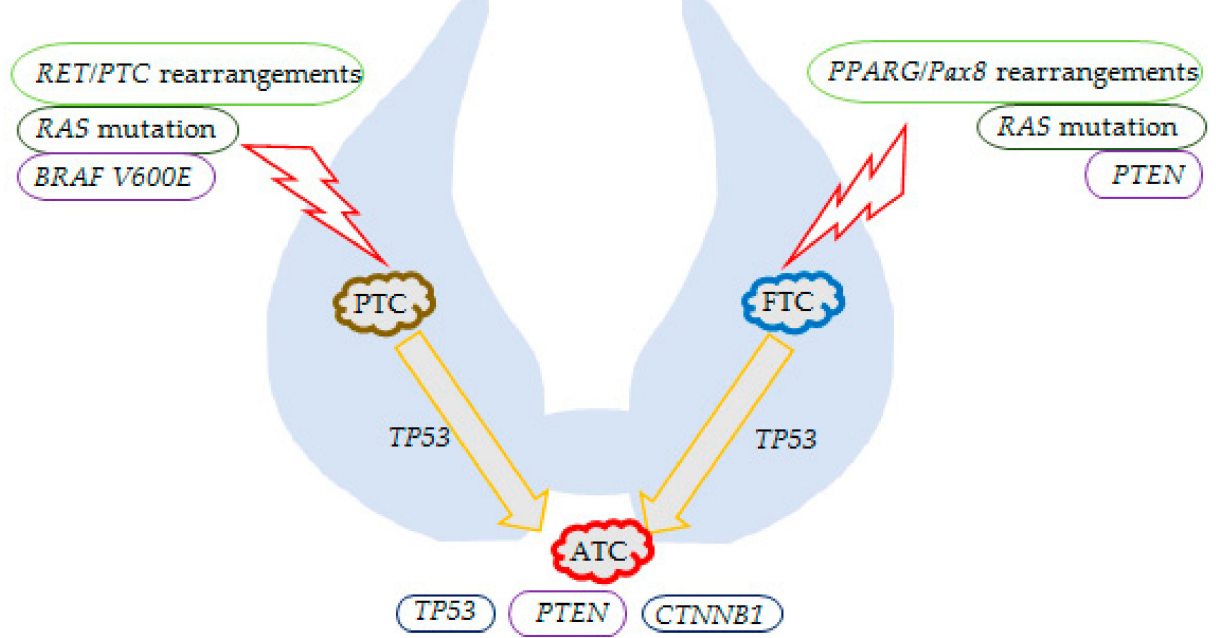

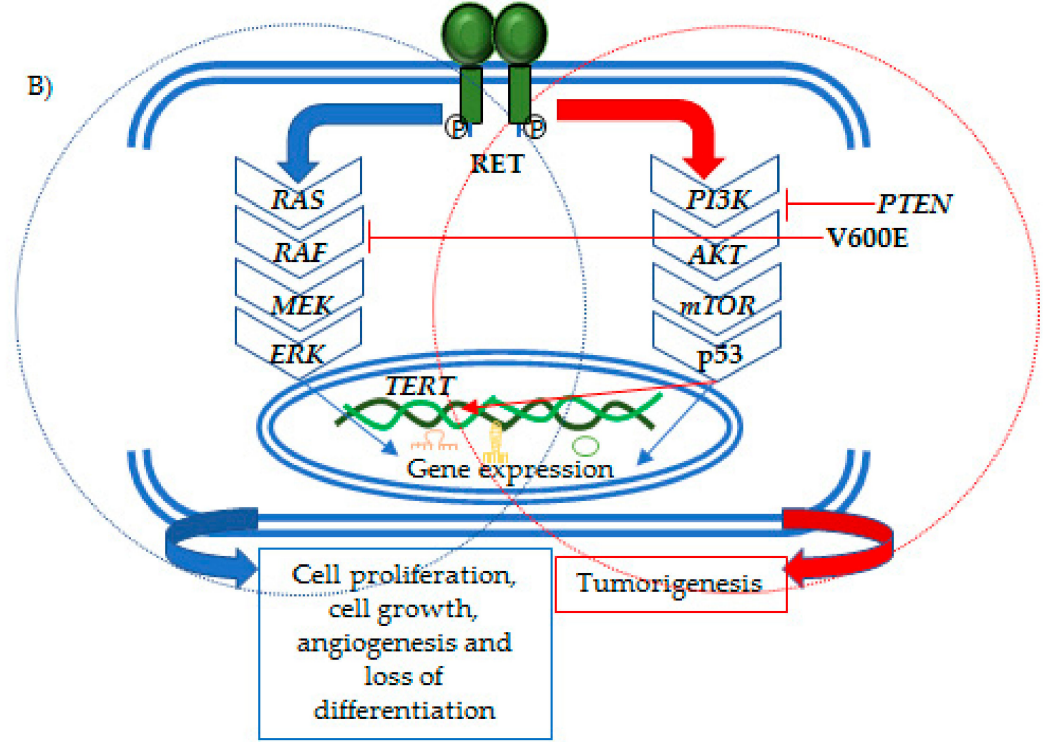

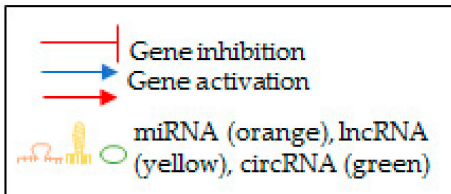

Figure 1. Progression of thyroid cancer and the main genetic alterations involved in such process. (A) Picture depicting thyroid cancer hystotypes and their causative genetic events. PTCs present BRAF (V600E substitution), RAS mutations, and/or RET/PTC rearrangements. FTCs display PPARc/Pax8 rearrangements, RAS mutations, and PTEN inactivating mutations or deletions. ATCs are characterized by PTEN and CTNNB1 mutations and p53 inactivation. (B) Schema shows the key molecular signaling pathways involved in thyroid cancer. On the left (inside the circle with dashed blue line): MAPK pathway, which is activated in most thyroid cancers after a mutational event. Once thyroid cancer development is initiated, gene expression is altered, evoking cell proliferation, cell growth, angiogenesis, and loss of differentiation. On the right (inside the circle with dashed red line): pathways altered in advanced thyroid cancers, which promote tumor progression. This includes the PI3K-mTOR pathway, the p53 tumor suppressor, and alterations in the promoter for TERT. miRNAs, lncRNAs and circRNAs are also represented inside the nucleus as genetic players in thyroid cancer development. 
Thus, RET rearrangements are determinant on the evaluation of thyroid nodules with undefined cytology. The main RET/PTC oncoproteins are summarized in Table 1.

Table 1. RET/PTC oncoproteins related with thyroid cancer.

\begin{tabular}{|c|c|c|c|}
\hline $\begin{array}{c}\text { RET/PTC } \\
\text { Rearrangement }\end{array}$ & Fusion Partner & $\begin{array}{l}\text { Chromosomal } \\
\text { Alteration }\end{array}$ & Reference \\
\hline RET/PTC1 & Coiled-coil domain-containing protein 6 (CCDC6) & inv10(q11.2;q21) & [29] \\
\hline RET/PTC2 & $\begin{array}{l}\text { Protein kinase, cAMP-dependent, regulatory, type I, } \\
\text { alpha (PRKAR1A) }\end{array}$ & $\mathrm{t}(10 ; 17)(\mathrm{q} 11.2 ; \mathrm{q} 23)$ & [30] \\
\hline RET/PTC3 & $\begin{array}{l}\text { Nuclear coactivator } 4 \text { (RET-fused gene, androgen } \\
\text { receptor-associated protein 70) (NCoa4 (RFG, ARA70) }\end{array}$ & inv10(q11.2;q10) & [29] \\
\hline RET/PTC4 & $\begin{array}{l}\text { Nuclear coactivator } 4 \text { (RET-fused gene, androgen } \\
\text { receptor-associated protein 70) (NCoa4 (RFG, ARA70) }\end{array}$ & $\operatorname{inv10(q11.2;q10)}$ & [31] \\
\hline RET/PTC5 & RET-fused gene 5 (Golgin A5) (RFG5 (GOLGA5)) & $\mathrm{t}(10 ; 14)(\mathrm{q} 11.2 ; \mathrm{q} 32)$ & [32] \\
\hline RET/PTC6 & Tripartite motif-containing 24 (TRIM24) & $\mathrm{t}(7 ; 10)(\mathrm{q} 32-\mathrm{q} 34 ; \mathrm{q} 11.2)$ & [33] \\
\hline RET/PTC7 & $\begin{array}{c}\text { RET-fused gene } 7 \text { (tripartite motif-containing } 33 \\
\text { (RFG7(TRIM33)) }\end{array}$ & $\mathrm{t}(1 ; 10)(\mathrm{p} 13 ; \mathrm{q} 11.2)$ & [33] \\
\hline RET/PTC8 & Kinectin 1 (KTN1) & $\mathrm{t}(10 ; 14)(\mathrm{q} 11.2 ; \mathrm{q} 22.1)$ & [34] \\
\hline RET/PTC9 & RET-fused gene 9 (RFG9) & $\mathrm{t}(10 ; 18)(\mathrm{q} 11.2 ; \mathrm{q} 21-22)$ & [35] \\
\hline RET/ELKS & $\begin{array}{l}\text { Glutamate, leucine, lysine, serine-rich sequence } \\
\text { (RAB6-interacting protein 2) (ELKS (RAB6IP2)) }\end{array}$ & $\mathrm{t}(10 ; 12)(\mathrm{q} 11.2 ; \mathrm{p} 13.3)$ & [36] \\
\hline RET/PCM1 & Pericentriolar material 1 (PCM1) & $\mathrm{t}(8 ; 10)(\mathrm{q} 21-22 ; \mathrm{q} 11.2)$ & [37] \\
\hline RET/RFP & $\begin{array}{l}\text { RET finger protein (tripartite motif-containing 27) } \\
\text { (RFP (TRIM27)) }\end{array}$ & $\mathrm{t}(6 ; 10)(\mathrm{p} 21 ; \mathrm{q} 11.2)$ & [38] \\
\hline RET/HOOK3 & Hook homolog 3 (HOOK3) & $\mathrm{t}(8 ; 10)(\mathrm{p} 11.21 ; \mathrm{q} 11.2)$ & [39] \\
\hline
\end{tabular}

\subsubsection{Other Somatic RET Mutations}

The genetic bases for nearly all thyroid cancers have been solved through DNA sequencing studies. Most thyroid tumors harbor mutations that eventually activate MAPK and PI3K-AKT signaling pathways, which regulate cellular proliferation $[3,40,41]$. Furthermore, somatic $R E T$ mutations appear in $40-50 \%$ of sporadic MTCs and have been linked with a worse prognosis for patients. In fact, the presence of a somatic RET mutation is associated with lymph node metastases at diagnosis, which is a bad prognostic factor for complete cure for such patients [22]. Somatic RET mutations have been described in sporadic cases of MTC [42] as well as loss of heterozygosity at different loci (deletions of tumor suppressor genes) in MTC [21]. In addition, a mutation in codon 664 of the RET gene, which affects the protein kinase domain of the gene product by changing a threonine for a methionine, was found in unrelated MEN2B patients as well as in six sporadic tumors [43].

The application of new approaches has improved the knowledge of somatic RET mutations such as $R E T^{\mathrm{M} 918 \mathrm{~T}}$ mutation. A genome-wide DNA methylation profiling was performed in a large MTC series. Integration of methylation data together with mRNA and miRNA expression data revealed JAK/Stat signaling effector STAT3 as a potential therapeutic target for these tumors [44].

\subsection{Germline RET Mutations}

Gain-of-function RET mutations give rise to MEN2 [23,45]. In MEN2, mutations in the RET intracellular domains lead to activation of RET monomers while in the extracellular domain carry to dimerization [23,46]. Thus, MEN2 RET receptors constitutively activate signaling pathways linked to wildtype RET activity $[47,48]$. In fact, MEN2 phenotype is more severe when specific RET mutations lead to increased kinase activity [49,50]. Based on these observations, the clinical management 
guidelines for MEN2 patients recommend early genetic screening in at-risk individuals, in order to determine if they carry any RET mutation, which is associated with the poorest prognosis [50]. There are three American Thyroid Association categories: I) moderate-risk mutations (exon 10, exon 11 mutations other than codon 634, and exons 13 through 15), which lead to relatively late MTC onset; II) high-risk mutations (exon 11, codon 634, the classical MEN2A mutation; and exon 15, codon 883), which present intermediate risk; and III) highest-risk mutations, with the typical MEN2B mutation (exon 16, codon 918), which confer the highest risk of early MTC development and growth [51]. All updated information regarding the effect of RET mutations on sporadic and familial cases of thyroid cancer is compiled in different reviews $[26,52,53]$.

More than $95 \%$ of MEN2 cases have germline mutations in the RET proto-oncogene, leading to a constitutive activation of the metabolic pathways of RET signaling [54]. Of those patients, $98 \%$ have mutations grouped in a hotspot composed of five cysteine codons present in the extracellular domain of the protein (C609, C611, C618, C620, C630, C634) [49,55,56]. Eighty-seven percent of MEN2A patients carry mutations affecting codon 634, C634R being the most prevalent one that has been detected [49], unlike in the Spanish population, who mostly carry the C634Y mutation [57-60]. In addition, although over 70 RET mutations have been described in MEN2A patients (all in the extracellular region, close to the transmembrane domain), only two RET mutations (affecting codons 918 and 883) have been linked to MEN2B [61].

Regarding FMTC missense mutations in the tyrosine kinase domain, one changes glutamate 768 for an aspartate and another one substitutes valine 804 for a leucine. In addition, there are some relevant mutations on cysteine codons and the transmembrane domain, some of them shared with MEN2A syndrome, which are updated and summarized in Figure 2. Both are gain-of-function mutations and result in aberrant signaling mediated by RET $[42,62,63]$. 


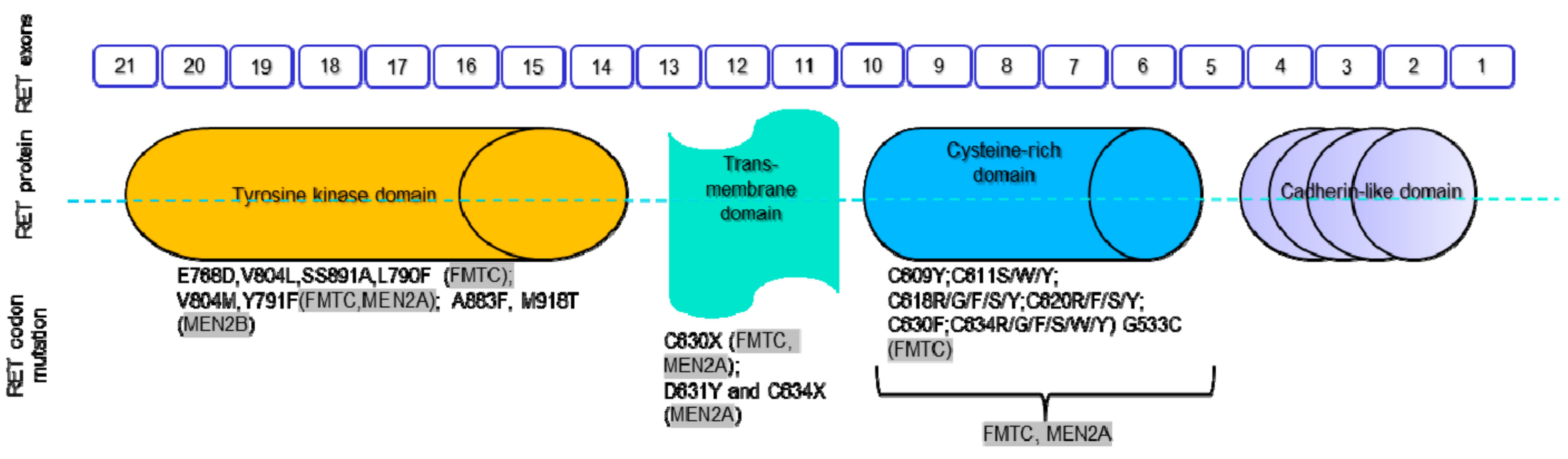

Figure 2. Schematic structure of RET, and mutations identified in MEN2A, MEN 2B and familial medullary thyroid carcinoma (FMTC). Modified from [64,65]. 


\subsection{Susceptibility Factors}

A germline RET S836S variant (c.2508C > T, rs1800862) has been correlated with somatic RET ${ }^{\mathrm{M} 918 \mathrm{~T}}$ mutation in exon 16, which leads to a more aggressive sMTC. Furthermore, this variant was found to have a significantly higher frequency in sMTC compared to controls, which led to it being considered as the first genetic susceptibility factor for the disease [64,66-68]. Additionally, IVS1-126G > T (c.74-126G > T, rs2565206) and G691S (c.2071G>A, rs1799939, p.Gly691Ser)/S904S (c.2712C>G, rs1800863) have also been described as associated with sMTC in several populations although this finding was not replicated in a larger study [69]. The RET $\mathrm{c} * 587 \mathrm{~T}>\mathrm{C}$ variant was restricted to the Italian population [70-73].

It has been suggested that variants in genes encoding for RET coreceptors might play a role in the pathogenesis of sMTC. A study of the German population showed that GFRA1-193C $>$ G and c.537T $>C$ were overrepresented in sMTC versus controls, which suggested that both variants could be in linkage disequilibrium with other locus responsible for the disease. However, such overrepresentation was not found in a similar study of the Spanish population, supporting a founder effect of both variants in Germany [74].

\section{BRAF}

The most frequent mutations (60\%) in PTC patients are found on the BRAF gene. Moreover, the $B R A F^{V 600 E}$ mutation (p.Val600Glu; commonly known as V600E), which is found in $95 \%$ of cases, is used as a risk biomarker in PTC [20]. Although somatic mutations in this gene are absent on benign thyroid nodules, they appear on a third of anaplastic thyroid cancers [75,76]. As we mentioned above, the majority of $B R A F$ mutations implicate the activation of the kinase domain of this protein, which finally dysregulates the MAPK signaling pathway [77-79], thus being relevant in cellular processes implicated in cancer development such as tumorigenesis, proliferation, and progression [80,81].

\section{RAS}

The RAS genes (H-RAS, N-RAS, K-RAS) present somatic point mutations in follicular adenoma, FTC (40-53\%), PTC (0-20\%), fvPTC (17-25\%), and poorly differentiated and anaplastic thyroid cancer $(20-60 \%)$ [19,75,82-85]. A codon 61 mutation of NRAS (N2) was identified four times more frequently in follicular tumors than in papillary cancers, and it is the second most common point mutation with an incidence of $8.5 \%$ [20]. Thus, RAS mutations are associated with follicular tumors that compile from a preinvasive lesion to a true malignancy, either FTC, PTC, fvPTC, or poorly differentiated thyroid cancer $[84,86]$. RAS mutations together with TERT promoter mutations (C228T and C250T) have been associated with more aggressive and recurrent thyroid tumor and patient mortality, especially in PTC patients. Although further studies are needed, these outcomes indicate that TERT is a new oncogene in thyroid cancer and promoter mutations may be promising in clinical management of thyroid cancer, especially in combination with BRAF V600E or RAS mutations [87].

\section{PAX8-PPARG}

The PAX8-PPARG fusion protein is the product of a $\mathrm{t}(2 ; 3)(\mathrm{q} 13 ; \mathrm{p} 25)$ chromosomal translocation, which used to be linked to FTC, and presents oncogenic capacity in transgenic mice [88]. PAX8-PPARG-positive tumors present a more prominent vascular and capsular invasion than RAS-positive tumors [16].

\section{Other Genes}

In ATC the accumulation of several oncogenic alterations is equivalent to an increased level of dedifferentiation and aggressiveness [89]. The role that P53 plays in thyroid carcinogenesis is well known, but the role of the remaining P53 family members in thyroid cancer needs further studies. Increasing evidence indicates that such family members favor the development of multiple thyroid cancer variants, and in addition they are being used as therapeutical targets [90]. 
Furthermore, there is a lack of knowledge of pathways specifically associated with each RET mutation and with non-RET-mutated sporadic MTC. A transcriptional profile assay, together with pathway enrichment analysis and gene ontology biological processes, revealed that PROM1 could be necessary for the survival of tumoral cells in this tumor [91].

In addition, a novel constitutional frameshift c.948delT mutation (p.G318Afs*22) in ESR2 was found to segregate with MTC (without any identifiable RET mutation) [92]. However, this mutation was not found in other series of patients, such as FMTC cases [93].

Rearrangements involving the anaplastic lymphoma kinase (ALK) gene with the striatin (STRN) gene have been described, which constitutively activate ALK kinase, inducing tumor formation in nude mice. Such fusion may represent a therapeutic target for patients with highly aggressive types of thyroid cancer [94]. Moreover, the ETV6-NTRK3 rearrangement, exclusively found in fvPTC, together with $S T R N-A L K$ are recurrent and absent in benign lesions, which could be useful for the diagnosis of thyroid nodules [95].

There is a thyroid specific transcription factor, FOXE1, which plays an essential role in thyroid development. Among other functions, it recognizes sites in thyroglobulin and thyroperoxidase and it also aids in maintaining cellular differentiation in the adult thyroid. Some genes increase its expression (Adamts9, Cdh1, Duox2, and S100a4) in the absence of FOXE1, while Casp4, Creld2, Dusp5, Etv5, Hsp5a, Nr4a2, and Tm4sf1 decrease [96]. FOXE1 has been associated with hypothyroidism and PTC [97]. A single nucleotide polymorphism in FOXE1 rs965513 which has been related with differentiated thyroid cancers in Caucasian population [98]

A compilation of the main genes related with the disease, indicating their location, their main type of alterations (somatic or germline mutations) and their incidence on the disease has been included in Table 2.

Table 2. Most relevant genes in thyroid cancer.

\begin{tabular}{|c|c|c|c|c|c|}
\hline Gene & $\begin{array}{l}\text { Chromosome } \\
\text { (Chr) }\end{array}$ & Type of Alteration & $\begin{array}{l}\text { Origin of } \\
\text { Mutation }\end{array}$ & Disease & Reference \\
\hline \multirow{3}{*}{$\operatorname{RET}\left({ }^{*}\right)$} & \multirow{3}{*}{ Chr 10} & $\begin{array}{c}\mathrm{RET} / \mathrm{PTC} \\
\text { rearrangements }\end{array}$ & Somatic & PTC & [26-28] \\
\hline & & \multirow{2}{*}{ Point mutations } & Somatic & sporadic MTC & {$[43,99]$} \\
\hline & & & Germline & $\begin{array}{c}\text { MEN2A [OMIM\# 171400]), MEN2B } \\
\text { [OMIM\#162300]) and FMTC [OMIM\# } \\
\text { 155240]) }\end{array}$ & {$[23,45]$} \\
\hline \multirow[t]{2}{*}{$B R A F$} & \multirow[t]{2}{*}{ Chr 7} & $\begin{array}{l}\text { V600E mutation } \\
\text { (p.Val600Glu) }\end{array}$ & Somatic & PTC & \multirow[t]{2}{*}[75,76]{} \\
\hline & & Point mutations & Somatic & ATC & \\
\hline$R A S\left(N_{-}, K_{-}, H_{-}\right)$ & $\begin{array}{l}\text { NRAS: Chr 1; } \\
\text { KRAS: Chr 12; } \\
\text { HRAS: Chr } 11\end{array}$ & Point mutations & Somatic & $\begin{array}{c}\text { follicular adenoma, FTC, PTC, fvPTC, } \\
\text { poorly differentiated and anaplastic } \\
\text { thyroid cancer }\end{array}$ & {$[19,75,82-85]$} \\
\hline PTEN & Chr 10 & $\begin{array}{c}\text { Insertions, deletions, } \\
\text { splice site mutations and } \\
\text { large deletions }\end{array}$ & Germline & $\begin{array}{c}\text { Cowden syndrome } 1 \text { (CWS1, [OMIM\# } \\
158350]\end{array}$ & [100] \\
\hline \multirow{2}{*}{ PIK3CA } & \multirow{2}{*}{ Chr 3} & \multirow{2}{*}{ Point mutations } & Somatic & PTC & [101] \\
\hline & & & Germline & $\begin{array}{l}\text { Cowden syndrome } 5 \text { (CWS5, [OMIM\# } \\
615108])\end{array}$ & [17] \\
\hline AKT1 & Chr 14 & Point mutations & Germline & $\begin{array}{c}\text { Cowden syndrome } 6 \text { (CWS6, [OMIM\# } \\
615109]\end{array}$ & [102] \\
\hline TERT Promoter & Chr 5 & $\begin{array}{l}\text { Mutations with a } \\
\text { co-occurrence with either } \\
B R A F \text { or } R A S \text { mutations }\end{array}$ & Somatic & ATC and advanced stages of FNMTC & {$[103,104]$} \\
\hline
\end{tabular}


Table 2. Cont.

\begin{tabular}{|c|c|c|c|c|c|}
\hline Gene & $\begin{array}{l}\text { Chromosome } \\
\text { (Chr) }\end{array}$ & Type of Alteration & $\begin{array}{l}\text { Origin of } \\
\text { Mutation }\end{array}$ & Disease & Reference \\
\hline$J A K 3$ & Chr 19 & Point mutations & Somatic & FTC & [105] \\
\hline \multirow{2}{*}{ TP53 } & \multirow{2}{*}{ Chr 17} & \multirow{2}{*}{ Point mutations } & Somatic & ATC, PDTC & {$[106,107]$} \\
\hline & & & Germline & $\begin{array}{l}\text { Li-Fraumeni syndrome (LFS, [OMIM\# } \\
151623])\end{array}$ & [108] \\
\hline CHEK2 & Chr 22 & $\begin{array}{l}\text { Deletions and point } \\
\text { mutations }\end{array}$ & Germline & $\begin{array}{l}\text { Li-Fraumeni syndrome } 2 \text { (LFS2, } \\
\text { [OMIM\# 609265]) }\end{array}$ & [109] \\
\hline MET & Chr 7 & Point mutations & Somatic & MTC & [110] \\
\hline$A L K$ & Chr 2 & Gene rearrangements & Somatic & PTC, PDTC and ATC & [111] \\
\hline \multirow{2}{*}{$A P C$} & \multirow{2}{*}{ Chr 5} & \multirow{2}{*}{ Point mutations } & Somatic & PTC & {$[112,113]$} \\
\hline & & & Germline & Gardner syndrome [OMIM\# 175100] & {$[113,114]$} \\
\hline CTNNB1 & Chr 3 & Point mutations & Somatic & PTC & [115] \\
\hline
\end{tabular}

(*) Databases including the registered RET variants up to date (October 25th, 2019): LOVD (v.3.0 Build 21c): https://databases.lovd.nl/shared/genes/RET. From the 146 RET variants reported, this database does not distinguish which ones are linked to thyroid cancer. Then, in order to see the specific variants associated with thyroid cancer, it is useful to visit https://databases.lovd.nl/shared/diseases\#id=0\&order=symbol\%2CASC\&search_name= thyroid\%20cancer\&page_size $=100 \&$ page $=1$. ClinVar: https://www.ncbi.nlm.nih.gov/clinvar/?term=RET\%5Bgene\% 5D+thyroid+cancer. There have been reported 813 RET variants linked to any form of thyroid cancer. HGMD: http://www.hgmd.cf.ac.uk/ac/gene.php?gene=RET. From the 395 registered RET mutations in this database, 133 of them are associated to thyroid cancer.

In summary, the molecular pathogenesis of differentiated thyroid cancer, with specific signaling pathways and activating point mutations, has been elucidated. When some of the specific genes mutate, the tumor become into more aggressive and advanced thyroid cancer. Some of those events, include: RAS mutations ( $25 \%$ in poorly differentiated thyroid cancers); activating mutations of PIK3CA; point mutation p.V600E in BRAF; mutations in CTNNB1 ( $\beta$-catenin) which is involved in Wnt signaling, and in TP53 (a tumor suppressor), which may participate in de-differentiation of these tumors [116,117]. In addition, copy-number gains (found in proto-oncogenes) or oncogenic gene amplifications are mostly found in poorly differentiated and anaplastic than in differentiated thyroid carcinomas, suggesting that these genetic alterations play an important role in the progression and aggressiveness of thyroid cancer. This is the case, for example, of the genes encoding receptor tyrosine kinases (RTKs) and P13K-AKT pathway members, where an increased protein expression will activate these signaling pathways [118]. Regarding $A L K$ gene, it was found in $9 \%$ of poorly differentiated thyroid cancers, $4 \%$ of ATC and $1 \%$ of PTC [119]. While MAPK and P13K-AKT pathways are firstly involved in differentiated thyroid carcinoma, when genetic alterations accumulate, both pathways get activated and an evolution of the tumor occurs into poorly differentiated and ATC [14].

\section{8. ncRNAs}

The global analysis of genomic variants, gene and microRNA (miRNA) expression, aberrant methylation, and proteomic profiles revealed that mutations in BRAF and RAS, together with RET-PTC fusions, are the most common genetic alterations in both FTC and PTC. However, epigenetic modulators, such as non-coding RNAs (ncRNAs), have recently emerged as helpful factors for both the diagnosis and treatment of these thyroid carcinomas. Specifically, ncRNAs such as miRNAs, circular RNAs (circRNAs), and long non-coding RNAS (lncRNAs) have been implicated in the modulation of gene expression that regulates cellular processes such as cell differentiation, proliferation, cell cycle, apoptosis, migration, and invasion [120-123]. Over the past four decades, thyroid cancer has emerged as a major health issue. Thus, the identification of novel molecular therapeutic targets for prognosis and diagnosis to advance in the overall management of this malignancy is really needed. Interestingly, ncRNAs have been identified together with epistatic gene interactions in SMTC and juvenile PTC, which help to understand the genetic architecture of complex diseases and support the relevance that these elements have to explain carcinoma development and progression [124,125]. 


\section{1. $m i R N A s$}

In the last twenty years, dysregulation of miRNAs have been linked to thyroid dysfunction and oncogenicity leading to this type of cancer $[122,126]$. MiRNAs are an important class of small regulatory RNAs with a length of $\sim 22 \mathrm{nt}$ that regulate post-transcription gene silencing $[127,128]$. They regulate gene expression by partial complementarity pairing with mRNAs, promoting their degradation or blocking translation. This gene regulation leads them to participate in many biological processes $[129,130]$. When thyroid malignant transformation occurs by MAPK oncogenes, a significant reduction of "tumor-suppressor" miRNAs and activation of oncogenic miRNAs take place [131]. The most relevant thyroid differentiation genes and transcription factors as predicted targets of microRNAs have been summarized in Table 3. The role of specific miRNAs in thyroid carcinogenesis is under intensive investigation, as new examples of miRNAs in cancer pathways are reported almost daily. As an example of such complexity, TCGA analysis unravel the presence of six miRNA clusters in PTC. Cluster 1 (RAS-mutated tumors and follicular variants) is enriched with the miRNAs miR-181 and miR-182, while BRAF tumors are contained in the rest of clusters (Clusters 2-6). Cluster 5 (with high levels of miR-146b and miR-375, and low levels of miR-204) and Cluster 6 (enriched with miR-21 and low levels of miR-204), are associated with the less-differentiated tumors and a higher risk of recurrence [132]. In summary, the upregulated miRNAs target factors that suppress pathway activation (of the three main signaling pathways activated in thyroid cancer-MAPK, PI3K, and TGF $\beta$ ), while the downregulated miRNAs target factors activating such pathways. In this scenario, those three pathways remain activated in thyroid cancer where miRNAs are functioning as crucial modulators of pathway activity. Then, they can be considered as potential therapeutic targets. 
Table 3. Targets of microRNAs: different genes and transcription factors have been described as targets of miRNAs.

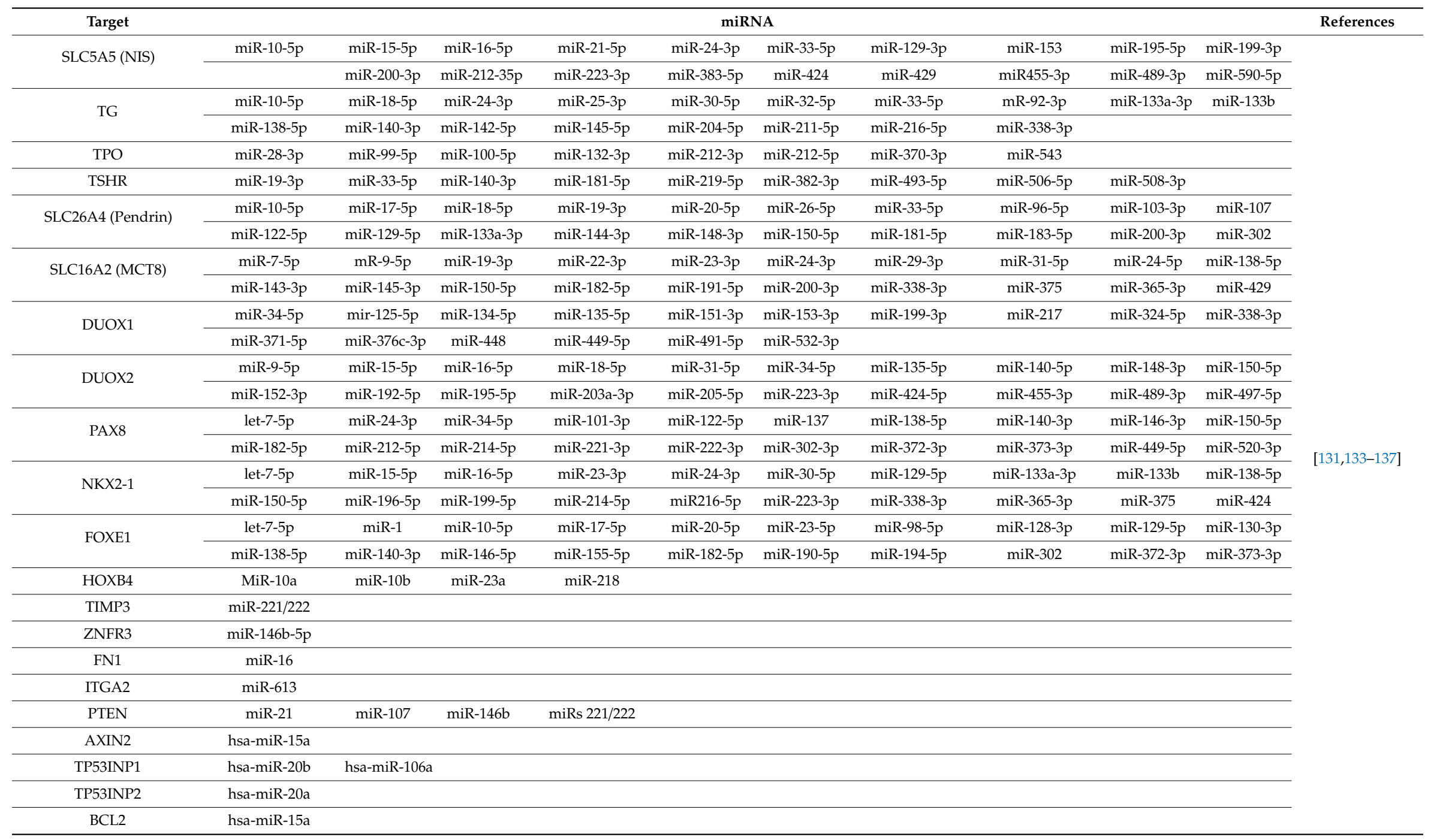


Table 3. Cont

\begin{tabular}{|c|c|c|c|c|c|c|c|c|c|c|}
\hline Target & & & & & & & & & & References \\
\hline KAT2B & hsa-miR-20a & & & & & & & & & \\
\hline PTEN & miR-15a & miR-19a & miR-19b & miR-21 & miR-24 & miR-107 & miR-146b p & miRs 221/222 & miR-486-5p & \\
\hline KIT & miRs 221/222 & & & & & & & & & \\
\hline AKT3, ZNRF3, Smad4 & miR-145 & & & & & & & & & \\
\hline p27Kip 1 & miRs 221/222 & & & & & & & & & \\
\hline SOCS4 & miR-25 & & & & & & & & & \\
\hline Sox17 & miR-595 & & & & & & & & & \\
\hline Pdcd 4 & $\mathrm{miR}-21$ & miR-183 & & & & & & & & \\
\hline ZEB1 and ZEB2 & miR-200 family & & & & & & & & & \\
\hline LOX & miR-29a & miR-30a & & & & & & & & \\
\hline $\begin{array}{l}\text { SLC7A5, ADAM9, LRP6, } \\
\text { CXCR4 }\end{array}$ & miR-126 & & & & & & & & & \\
\hline EGFR, CXCL 12 & miR-137 & & & & & & & & & \\
\hline MRTF-A & miR-206 & & & & & & & & & \\
\hline Rac1 & miR-101 & & & & & & & & & \\
\hline SphK2 & miR-613 & & & & & & & & & \\
\hline CARMA 1 & miR-539 & & & & & & & & & \\
\hline TUSC2, Rock1 & miR-584 & & & & & & & & & \\
\hline YAP1, SLC16a2, ERBB2 & miR-375 & & & & & & & & & \\
\hline VEGF-A & miR-205 & miR-126 & & & & & & & & \\
\hline $\mathrm{p} 85 \mathrm{~b}$ & miR-126 & & & & & & & & & \\
\hline
\end{tabular}




\section{2. $\ln R N A$ As}

More recently, many lncRNAs ( $>200 \mathrm{nt}$ or even several $\mathrm{kb}$ in length) have been described to be upregulated or downregulated in thyroid cancer tissues or cancer cell lines. Predicting miRNA/target duplex [138] is used to detect miRNA/lncRNA interaction [139].

They are expressed in a tissue-specific manner and involved in tumorigenesis acting through distinct molecular mechanisms on epigenetic modifications, transcriptional, and post-transcriptional processing. In this way, they are implicated in cell cycle, cell differentiation, proliferation, apoptosis, migration, and invasion [120,140]. However, the role and molecular mechanism that they play in thyroid cancer, compared to other malignancies, remains largely unclear. Their involvement in cancer pathogenesis and availability make lncRNAs ideal biomarkers for cancer prognosis and diagnosis. Just as an example, we will discuss the importance of three relevant lncRNAs in thyroid cancer such as H19, MALAT1, PTCSC3, among many others whose descriptions and their possible mechanism in thyroid cancer, known to date, are summarized in Table 4.

\subsubsection{H19}

H19 is a typical lncRNA that is associated with various cancer types, with both tumor promoter and suppressive functions [141]. Its expression is higher in thyroid tumor tissues, where enhance proliferation and migration, comparing with normal thyroid cells [142].

\subsubsection{Metastasis-Associated Lung Adenocarcinoma Transcript 1 (MALAT1)}

MALAT1 is a prooncogenic lncRNA in several cancer types [143]. Regarding thyroid cancer, MALAT1 is highly expressed in PTC than in FTC and ATC [144]. In addition, MALAT1 expression is higher in MTC than in normal thyroid [145].

\subsubsection{Papillary Thyroid Carcinoma Susceptibility Candidate 3 (PTCSC3)}

PTCSC3 is a lncRNA whose expression is strictly thyroid-specific and is downregulated either in thyroid tumor tissues and in thyroid cell lines. When PTCSC 3 acts as a tumor suppressor is a competing endogenous RNA for miR-574-5p [146].

Table 4. LncRNAs associated with thyroid cancer (TC).

\begin{tabular}{|c|c|c|}
\hline lncRNA & Role in Thyroid Cancer & References \\
\hline RP5-1024C24.1 & Associates negatively with late clinical stages & [147] \\
\hline CASC2 & Expression correlates with multifocality and TNM & [148] \\
\hline ENSG00000235070.3 & \multirow{2}{*}{ Correlates directly to BRAF (V600E) } & \multirow[t]{2}{*}{ [150] } \\
\hline ENSG00000255020.1 & & \\
\hline GAS8-AS1 & Low Expression negatively correlates with LNM & [152] \\
\hline NONHSAG051968 & Correlates negatively with tumor size & \multirow{3}{*}{ [153] } \\
\hline NONHSAG018271 & \multirow{2}{*}{ Suppresses tumor cell growth } & \\
\hline NONHSAG007951 & & \\
\hline MEG3 & Inhibits invasion and associates with LNM & [157] \\
\hline PTCSC2 & Predisposes genetically to thyroid cancer & [158] \\
\hline PTCSC3 & Suppresses cell growth and invasion & {$[159,160]$} \\
\hline
\end{tabular}


Table 4. Cont.

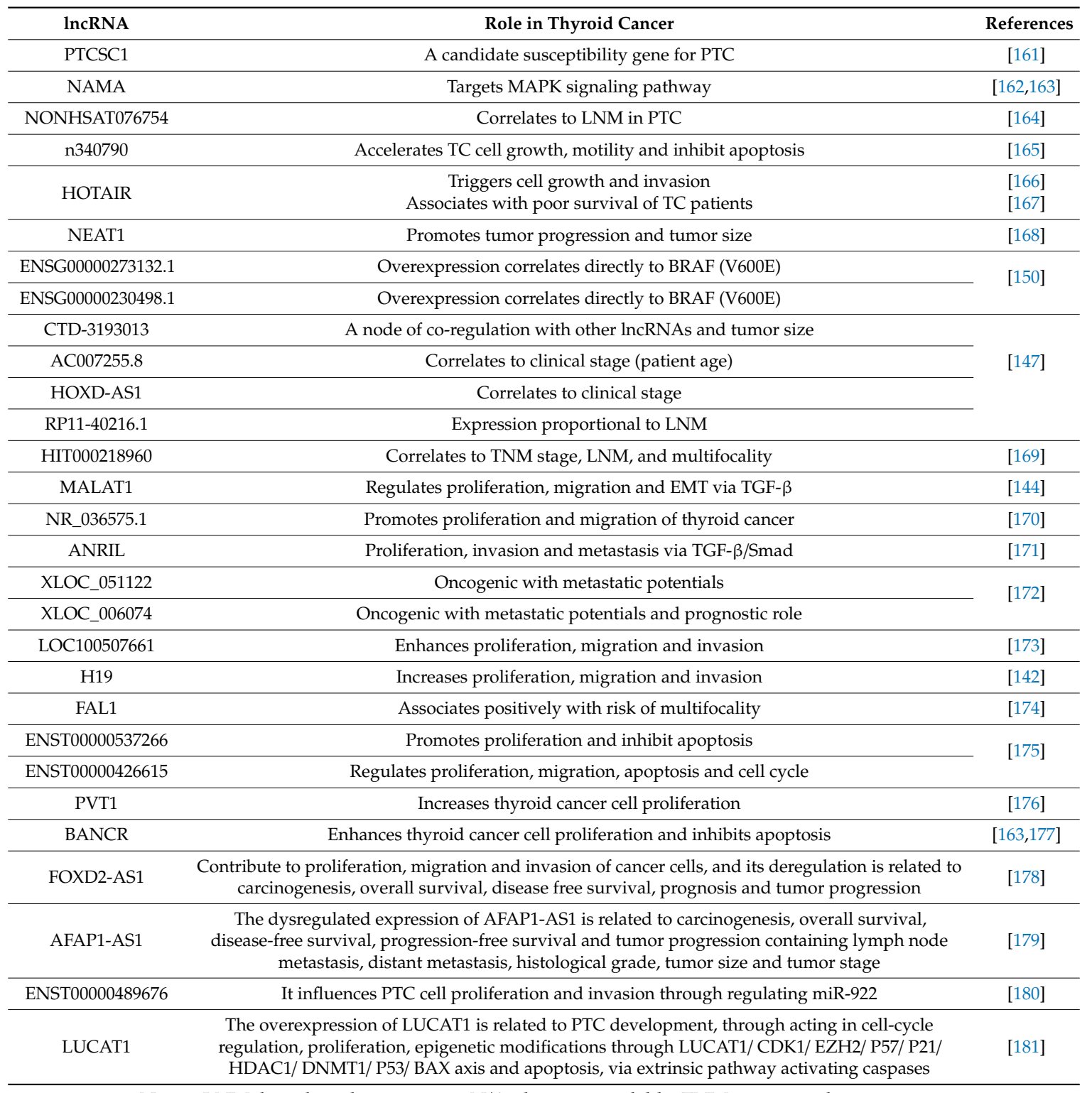

Notes: LNM, lymph node metastasis; N/A, data not available; TNM, tumor node metastasis.

\section{3. $\operatorname{circRNAs}$}

circRNAs were identified in human papillary thyroid cancer [182] and lately associated with different cancers [183-185]. There are four types: exonic circRNAs, circular RNAs from introns, exon-intron circRNAs, and intergenic circRNAs [186]. They are expressed in thousands of human genes and they have been suggested to modify gene expression through sponging miRNAs and interact with RNA-binding proteins, and they can also be positive regulators of their parental genes [187-189]. All circRNAs linked to thyroid cancer known to date have been compiled in Table 5 .

This is a very recent field of study in thyroid cancer and then, most of the circRNAs included in Table 5 are exclusively associated with this type of tumor, at least until today. Further studies are required to decipher if they are involved in the develop of some other tumors. However, four circRNAs have already been found in other cancers: circZFR, circ-ITCH, hsa_circ_0004458 and hsa_circRNA_100395. 
Table 5. CircRNAs described on thyroid cancer.

\begin{tabular}{|c|c|c|}
\hline circRNA & Role in Thyroid Cancer & Reference \\
\hline circMAN1A2 & Upregulated & [190] \\
\hline circRAPGEF5 & Upregulated; it acts through miR-198/FGFR1 & [191] \\
\hline Hsa_circ_0008274 & $\begin{array}{l}\text { Upregulated; it promotes cell proliferation and invasion } \\
\text { involving AMPK/mTOR signaling pathway in PTC }\end{array}$ & [194] \\
\hline $\operatorname{circZFR}$ & $\begin{array}{l}\text { Regulating miR-3619-5p/CTNNB1 axis and activating } \\
\text { Wnt/ } \beta \text {-catenin pathway. }\end{array}$ & [195] \\
\hline circRNA_102171 & $\begin{array}{l}\text { Upregulated; it promotes PTC progression through } \\
\text { activating Wnt/ } \beta \text {-catenin pathway in a } \\
\text { CTNNBIP1-dependent way }\end{array}$ & [196] \\
\hline circ-ITCH & $\begin{array}{l}\text { Upregulated; it suppresses papillary thyroid cancer } \\
\text { progression through miR-22-3p/CBL/ } \beta \text {-catenin pathway }\end{array}$ & [198] \\
\hline hsa_circ_0004458 & $\begin{array}{l}\text { Promoted the progression of PTC through inhibition of } \\
\text { miR-885-5p and activation of RAC1 }\end{array}$ & [199] \\
\hline $\begin{array}{l}\text { chr5: } 160757890-160763776-, \text { chr12: 40696591-40697936+, } \\
\text { chr7: } 22330794-22357656-, \text { chr21: 16386665-16415895-, chr7: } \\
\text { 91924203-91957214+, chr2: 179514891-179516047-, chr9: } \\
\text { 16435553-16437522-, and chr22: 36006931-36007153- }\end{array}$ & Up/downregulated & [200] \\
\hline circZFR & $\begin{array}{l}\text { Contributes to PTC cell proliferation and invasion by } \\
\text { sponging miR-1261 and facilitating C8orf4 expression }\end{array}$ & [201] \\
\hline
\end{tabular}

\section{Conclusions and Future Perspectives}

Thyroid cancer is a disease induced by progressive genetic and epigenetic molecular abnormalities. Most studies describe several classical aberrations involved in the tumorigenesis and progression of this tumor, such as point mutations, gene copy number variations, and aberrant gene methylation. Additionally, increasing evidence points to ncRNAs as important players in the regulation of a variety of biological functions of thyroid cancer cells (RNA stability, epigenetic processes, chromatin accessibility, translation, gene expression in mitochondria, anterograde and retrograde signaling, and intracellular and intercellular signaling) $[173,175,204]$. However, only a few structures of lncRNA are known. Furthermore, ncRNAs may be used for diagnosis, prognosis, and as potential therapeutic agents of thyroid cancer.

The genetic landscape of thyroid cancer is growing rapidly. Therapies that are targeted at genetic mutations related to this tumor are being used in patient care and clinical trials. In comparison with traditional disease-specific trials, molecular allocation studies ("basket studies") are testing targeted therapies in patients whose tumors carry particular mutations, in spite of the tumor type or origin [205]. These studies are more informative on anticancer therapies because they include a greater number of patients. Regarding thyroid cancers due to low prevalence mutations (i.e.: rearrangements of RET, NTRK1, NTRK3, or ALK), they could be included in trials with selective kinase inhibitors with probed efficacy in other types of cancer. Thus, targeted therapy in thyroid cancer has been mainly focused on tyrosine kinase inhibitors. Furthermore, cancer adaptation to hypoxia and angiogenesis through the transcription factor hypoxia-inducible factor 1-alpha has been found [4]. This factor is only present in cancer tissues and therefore could be a precision medicine paradigm for further research focused on drivers uniquely present in cancer tissues. 
Finally, the correlation of molecular profile (obtained by new sequencing technologies) with clinicopathological characteristics will lead to the development of novel precision therapies, reducing morbidity and mortality in thyroid cancer patients [206-208]. In this sense, differential response to a mitogen-activated protein kinase inhibitor was found to be related to the thyroid cancer genotype [209]. Molecular testing of mutation hotspots, rearrangements, and gene expression is now an effective diagnostic tool to better select patients for potential thyroid surgery $[210,211]$.

The TCGA project mentioned in this review [20] shifts the focus regarding thyroid cancer classification to a strong multidimensional genomic and integrative approach, which has relevant consequences on basic pathobiology, tumor classification, and therapies. In this manner, thyroid cancer therapy would enter the realm of precision medicine, which will favor a more personalized approach to this pathology, achieving, ultimately, greater hope and quality of life for patients.

In summary, the diagnosis and treatment of thyroid cancer is nowadays influenced by the molecular characterization of thyroid cancer types. The improvement of such techniques would help to reduce unnecessary treatments in indolent thyroid cancers, as well as improve the outcomes in patients with clinically aggressive cancers.

Author Contributions: B.L.-T.: draft the manuscript; R.M.F., L.V.-B., A.T., and G.A.: reviewing of the manuscript. S.B.: reviewing of the manuscript and funding acquisition. All authors have approved the submitted version and agree to be personally accountable for the author's own contributions and for ensuring that questions related to the accuracy or integrity of any part of the work, even ones in which the author was not personally involved, are appropriately investigated, resolved, and documented in the literature.

Funding: This study was supported by Instituto de Salud Carlos III (ISCIII), Spanish Ministry of Economy and competitiveness, Spain, and co-funded by European Union (ERDF/ESF, "Investing in your future") [PI16/0142]. CIBERER is an initiative of the ISCIII, Spanish Ministry of Economy and Competitiveness.

Conflicts of Interest: The authors declare no conflicts of interest.

\section{References}

1. Goodarzi, E.; Moslem, A.; Feizhadad, H.; Jarrahi, A.M.; Adineh, H.A.; Sohrabivafa, M.; Khazaei, Z. Epidemiology, Incidence and Mortality of Thyroid Cancer and their Relationship with the Human Development Index in the World: An Ecology Study in 2018. Adv. Hum. Biol. 2019, 9, 162-167. [CrossRef]

2. ASCO. Thyroid Cancer: Statistics. Available online: https://www.cancer.net/cancer-types/thyroid-cancer/ statistics (accessed on 1 September 2019).

3. Cabanillas, M.E.; McFadden, D.G.; Durante, C. Thyroid cancer. Lancet 2016, 388, 2783-2795. [CrossRef]

4. Xing, M. Molecular pathogenesis and mechanisms of thyroid cancer. Nat. Rev. Cancer 2013, 13, $184-199$. [CrossRef] [PubMed]

5. Guilmette, J.; Nose, V. Hereditary and familial thyroid tumours. Histopathology 2018, 72, 70-81. [CrossRef]

6. Peiling Yang, S.; Ngeow, J. Familial non-medullary thyroid cancer: Unraveling the genetic maze. Endocr. Relat. Cancer 2016, 23, R577-R595. [CrossRef]

7. Ruiz-Ferrer, M.; Fernandez, R.M.; Navarro, E.; Antinolo, G.; Borrego, S. G534E Variant in HABP2 and Nonmedullary Thyroid Cancer. Thyroid 2016, 26, 987-988. [CrossRef]

8. Ye, F.; Gao, H.; Xiao, L.; Zuo, Z.; Liu, Y.; Zhao, Q.; Chen, H.; Feng, W.; Fu, B.; Sun, L.; et al. Whole exome and target sequencing identifies $M A P 2 K 5$ as novel susceptibility gene for familial non-medullary thyroid carcinoma. Int. J. Cancer 2019, 144, 1321-1330. [CrossRef]

9. Ruiz-Llorente, S.; Montero-Conde, C.; Milne, R.L.; Moya, C.M.; Cebrian, A.; Leton, R.; Cascon, A.; Mercadillo, F.; Landa, I.; Borrego, S.; et al. Association study of 69 genes in the ret pathway identifies low-penetrance loci in sporadic medullary thyroid carcinoma. Cancer Res. 2007, 67, 9561-9567. [CrossRef]

10. Vriens, M.R.; Suh, I.; Moses, W.; Kebebew, E. Clinical features and genetic predisposition to hereditary nonmedullary thyroid cancer. Thyroid 2009, 19, 1343-1349. [CrossRef]

11. NCBI. Available online: https://www.ncbi.nlm.nih.gov/books/NBK1257/ (accessed on 01 September 2019).

12. Eng, C. RET proto-oncogene in the development of human cancer. J. Clin. Oncol. 1999, 17, 380-393. [CrossRef]

13. Saji, M.; Ringel, M.D. The PI3K-Akt-mTOR pathway in initiation and progression of thyroid tumors. Mol. Cell Endocrinol. 2010, 321, 20-28. [CrossRef] [PubMed] 
14. Xing, M. Genetic alterations in the phosphatidylinositol-3 kinase/Akt pathway in thyroid cancer. Thyroid 2010, 20, 697-706. [CrossRef] [PubMed]

15. Dwight, T.; Thoppe, S.R.; Foukakis, T.; Lui, W.O.; Wallin, G.; Hoog, A.; Frisk, T.; Larsson, C.; Zedenius, J. Involvement of the PAX8/peroxisome proliferator-activated receptor gamma rearrangement in follicular thyroid tumors. J. Clin. Endocrinol. Metab. 2003, 88, 4440-4445. [CrossRef] [PubMed]

16. Nikiforova, M.N.; Lynch, R.A.; Biddinger, P.W.; Alexander, E.K.; Dorn, G.W., 2nd; Tallini, G.; Kroll, T.G.; Nikiforov, Y.E. RAS point mutations and PAX8-PPAR $\gamma$ rearrangement in thyroid tumors: Evidence for distinct molecular pathways in thyroid follicular carcinoma. J. Clin. Endocrinol. Metab. 2003, 88, 2318-2326. [CrossRef] [PubMed]

17. Nikiforova, M.N.; Nikiforov, Y.E. Molecular diagnostics and predictors in thyroid cancer. Thyroid 2009, 19, 1351-1361. [CrossRef]

18. Xing, M. BRAF mutation in papillary thyroid cancer: Pathogenic role, molecular bases, and clinical implications. Endocr. Rev. 2007, 28, 742-762. [CrossRef]

19. Vasko, V.; Ferrand, M.; Di Cristofaro, J.; Carayon, P.; Henry, J.F.; de Micco, C. Specific pattern of RAS oncogene mutations in follicular thyroid tumors. J. Clin. Endocrinol. Metab. 2003, 88, 2745-2752. [CrossRef]

20. Agrawal, N.; Akbani, R.; Aksoy, B.A.; Ally, A.; Arachchi, H.; Asa, S.L.; Behera, M. Integrated genomic characterization of papillary thyroid carcinoma. Cell 2014, 159, 676-690. [CrossRef]

21. Mulligan, L.M.; Gardner, E.; Smith, B.A.; Mathew, C.G.; Ponder, B.A. Genetic events in tumour initiation and progression in multiple endocrine neoplasia type 2. Genes Chromosomes Cancer 1993, 6, 166-177. [CrossRef]

22. Elisei, R.; Cosci, B.; Romei, C.; Bottici, V.; Renzini, G.; Molinaro, E.; Agate, L.; Vivaldi, A.; Faviana, P.; Basolo, F.; et al. Prognostic significance of somatic RET oncogene mutations in sporadic medullary thyroid cancer: A 10-year follow-up study. J. Clin. Endocrinol. Metab. 2008, 93, 682-687. [CrossRef]

23. Mulligan, L.M. RET revisited: Expanding the oncogenic portfolio. Nat. Rev. Cancer 2014, 14, $173-186$. [CrossRef]

24. Cordioli, M.I.; Moraes, L.; Alves, M.T.; Delcelo, R.; Monte, O.; Longui, C.A.; Cury, A.N.; Cerutti, J.M. Thyroid-Specific Genes Expression Uncovered Age-Related Differences in Pediatric Thyroid Carcinomas. Int. J. Endocrinol. 2016, 2016, 1956740. [CrossRef]

25. Pillai, S.; Gopalan, V.; Smith, R.A.; Lam, A.K. Diffuse sclerosing variant of papillary thyroid carcinoma-An update of its clinicopathological features and molecular biology. Crit. Rev. Oncol. Hematol. 2015, 94, 64-73. [CrossRef]

26. Romei, C.; Ciampi, R.; Elisei, R. A comprehensive overview of the role of the RET proto-oncogene in thyroid carcinoma. Nat. Rev. Endocrinol. 2016, 12, 192-202. [CrossRef]

27. Viglietto, G.; Chiappetta, G.; Martinez-Tello, F.J.; Fukunaga, F.H.; Tallini, G.; Rigopoulou, D.; Visconti, R.; Mastro, A.; Santoro, M.; Fusco, A. RET/PTC oncogene activation is an early event in thyroid carcinogenesis. Oncogene 1995, 11, 1207-1210.

28. Khan, M.S.; Qadri, Q.; Makhdoomi, M.J.; Wani, M.A.; Malik, A.A.; Niyaz, M.; Masoodi, S.R.; Andrabi, K.I.; Ahmad, R.; Mudassar, S. RET/PTC Gene Rearrangements in Thyroid Carcinogenesis: Assessment and Clinico-Pathological Correlations. Pathol. Oncol. Res. 2018. [CrossRef]

29. Nikiforov, Y.E. RET/PTC rearrangement in thyroid tumors. Endocr. Pathol. 2002, 13, 3-16. [CrossRef]

30. Sozzi, G.; Bongarzone, I.; Miozzo, M.; Borrello, M.G.; Blutti, M.G.; Pilotti, S.; Della Porta, G.; Pierotti, M.A. A t $(10 ; 17)$ translocation creates the RET/PTC2 chimeric transforming sequence in papillary thyroid carcinoma. Genes Chromosomes Cancer 1994, 9, 244-250. [CrossRef]

31. Fugazzola, L.; Pierotti, M.A.; Vigano, E.; Pacini, F.; Vorontsova, T.V.; Bongarzone, I. Molecular and biochemical analysis of RET/PTC4, a novel oncogenic rearrangement between RET and ELE1 genes, in a post-Chernobyl papillary thyroid cancer. Oncogene 1996, 13, 1093-1097.

32. Rabes, H.M.; Klugbauer, S. Molecular genetics of childhood papillary thyroid carcinomas after irradiation: High prevalence of RET rearrangement. Recent Results Cancer Res. 1998, 154, 248-264.

33. Klugbauer, S.; Rabes, H.M. The transcription coactivator HTIF1 and a related protein are fused to the RET receptor tyrosine kinase in childhood papillary thyroid carcinomas. Oncogene 1999, 18, 4388-4393. [CrossRef]

34. Salassidis, K.; Bruch, J.; Zitzelsberger, H.; Lengfelder, E.; Kellerer, A.M.; Bauchinger, M. Translocation $\mathrm{t}(10 ; 14)$ (q11.2:q22.1) fusing the kinetin to the RET gene creates a novel rearranged form (PTC8) of the RET proto-oncogene in radiation-induced childhood papillary thyroid carcinoma. Cancer Res. 2000, 60, 2786-2789. 
35. Nikiforov, Y.E. Recent Developments in the Molecular Biology of the Thyroid. In Endocrine Pathology: Differential Diagnosis and Molecular Advances; Lloyd, R.V., Ed.; Humana Press: Totowa, NJ, USA, 2010.

36. Nakata, T.; Kitamura, Y.; Shimizu, K.; Tanaka, S.; Fujimori, M.; Yokoyama, S.; Ito, K.; Emi, M. Fusion of a novel gene, ELKS, to RET due to translocation $\mathrm{t}(10 ; 12)(\mathrm{q} 11 ; \mathrm{p} 13)$ in a papillary thyroid carcinoma. Genes Chromosomes Cancer 1999, 25, 97-103. [CrossRef]

37. Corvi, R.; Berger, N.; Balczon, R.; Romeo, G. RET/PCM-1: A novel fusion gene in papillary thyroid carcinoma. Oncogene 2000, 19, 4236-4242. [CrossRef]

38. Saenko, V.; Rogounovitch, T.; Shimizu-Yoshida, Y.; Abrosimov, A.; Lushnikov, E.; Roumiantsev, P.; Matsumoto, N.; Nakashima, M.; Meirmanov, S.; Ohtsuru, A.; et al. Novel tumorigenic rearrangement, $\Delta \mathrm{rfp} / \mathrm{ret}$, in a papillary thyroid carcinoma from externally irradiated patient. Mutat. Res. 2003, 527, 81-90. [CrossRef]

39. Ciampi, R.; Giordano, T.J.; Wikenheiser-Brokamp, K.; Koenig, R.J.; Nikiforov, Y.E. HOOK3-RET: A novel type of RET/PTC rearrangement in papillary thyroid carcinoma. Endocr. Relat. Cancer 2007, 14, 445-452. [CrossRef]

40. Hanahan, D.; Weinberg, R.A. Hallmarks of cancer: The next generation. Cell 2011, 144, 646-674. [CrossRef]

41. Rebai, M.; Rebai, A. Molecular genetics of thyroid cancer. Genet. Res. 2016, 98, e7. [CrossRef]

42. Eng, C.; Mulligan, L.M.; Smith, D.P.; Healey, C.S.; Frilling, A.; Raue, F.; Neumann, H.P.; Ponder, M.A.; Ponder, B.A. Low frequency of germline mutations in the RET proto-oncogene in patients with apparently sporadic medullary thyroid carcinoma. Clin. Endocrinol. 1995, 43, 123-127. [CrossRef]

43. Hofstra, R.M.; Landsvater, R.M.; Ceccherini, I.; Stulp, R.P.; Stelwagen, T.; Luo, Y.; Pasini, B.; Hoppener, J.W.; van Amstel, H.K.; Romeo, G.; et al. A mutation in the RET proto-oncogene associated with multiple endocrine neoplasia type 2B and sporadic medullary thyroid carcinoma. Nature 1994, 367, 375-376. [CrossRef]

44. Mancikova, V.; Montero-Conde, C.; Perales-Paton, J.; Fernandez, A.; Santacana, M.; Jodkowska, K.; Inglada-Perez, L.; Castelblanco, E.; Borrego, S.; Encinas, M.; et al. Multilayer OMIC Data in Medullary Thyroid Carcinoma Identifies the STAT3 Pathway as a Potential Therapeutic Target in RET(M918T) Tumors. Clin. Cancer Res. 2017, 23, 1334-1345. [CrossRef]

45. Wells, S.A., Jr. Advances in the management of MEN2: From improved surgical and medical treatment to novel kinase inhibitors. Endocr. Relat. Cancer 2018, 25, T1-T13. [CrossRef]

46. Plaza-Menacho, I. Structure and function of RET in multiple endocrine neoplasia type 2. Endocr. Relat. Cancer 2018, 25, T79-T90. [CrossRef]

47. Asai, N.; Iwashita, T.; Matsuyama, M.; Takahashi, M. Mechanism of activation of the ret proto-oncogene by multiple endocrine neoplasia 2A mutations. Mol. Cell Biol. 1995, 15, 1613-1619. [CrossRef]

48. Santoro, M.; Carlomagno, F.; Romano, A.; Bottaro, D.P.; Dathan, N.A.; Grieco, M.; Fusco, A.; Vecchio, G.; Matoskova, B.; Kraus, M.H.; et al. Activation of RET as a dominant transforming gene by germline mutations of MEN2A and MEN2B. Science 1995, 267, 381-383. [CrossRef]

49. Eng, C.; Clayton, D.; Schuffenecker, I.; Lenoir, G.; Cote, G.; Gagel, R.F.; van Amstel, H.K.; Lips, C.J.; Nishisho, I.; Takai, S.I.; et al. The relationship between specific RET proto-oncogene mutations and disease phenotype in multiple endocrine neoplasia type 2. International RET mutation consortium analysis. JAMA 1996, 276, 1575-1579. [CrossRef]

50. Wells, S.A., Jr.; Asa, S.L.; Dralle, H.; Elisei, R.; Evans, D.B.; Gagel, R.F.; Lee, N.; Machens, A.; Moley, J.F.; Pacini, F.; et al. Revised American Thyroid Association guidelines for the management of medullary thyroid carcinoma. Thyroid 2015, 25, 567-610. [CrossRef]

51. Voss, R.K.; Feng, L.; Lee, J.E.; Perrier, N.D.; Graham, P.H.; Hyde, S.M.; Nieves-Munoz, F.; Cabanillas, M.E.; Waguespack, S.G.; Cote, G.J.; et al. Medullary Thyroid Carcinoma in MEN2A: ATA Moderate- or High-Risk RET Mutations Do Not Predict Disease Aggressiveness. J. Clin. Endocrinol. Metab. 2017, 102, 2807-2813. [CrossRef]

52. Drilon, A.; Hu, Z.I.; Lai, G.G.Y.; Tan, D.S.W. Targeting RET-driven cancers: Lessons from evolving preclinical and clinical landscapes. Nat. Rev. Clin. Oncol. 2018, 15, 150. [CrossRef]

53. Mulligan, L.M. 65 years of the double helix: Exploiting insights on the RET receptor for personalized cancer medicine. Endocr. Relat. Cancer 2018, 25, T189-T200. [CrossRef]

54. Hansford, J.R.; Mulligan, L.M. Multiple endocrine neoplasia type 2 and RET: From neoplasia to neurogenesis. J. Med. Genet. 2000, 37, 817-827. [CrossRef] 
55. Accardo, G.; Conzo, G.; Esposito, D.; Gambardella, C.; Mazzella, M.; Castaldo, F.; Di Donna, C.; Polistena, A.; Avenia, N.; Colantuoni, V.; et al. Genetics of medullary thyroid cancer: An overview. Int. J. Surg. 2017, 41, S2-S6. [CrossRef]

56. De Groot, J.W.; Links, T.P.; Plukker, J.T.; Lips, C.J.; Hofstra, R.M. RET as a diagnostic and therapeutic target in sporadic and hereditary endocrine tumors. Endocr. Rev. 2006, 27, 535-560. [CrossRef]

57. Fernandez, R.M.; Navarro, E.; Antinolo, G.; Ruiz-Ferrer, M.; Borrego, S. Evaluation of the role of RET polymorphisms/haplotypes as modifier loci for MEN 2, and analysis of the correlation with the type of RET mutation in a series of Spanish patients. Int. J. Mol. Med. 2006, 17, 575-581. [CrossRef]

58. Sanchez, B.; Antinolo, G.; Navarro, E.; Japon, M.A.; Conde, A.F.; Astorga, R.; Borrego, S. Cys 634 mutations in the RET proto-oncogene in Spanish families affected by MEN 2A. Hum. Mutat. 1998, 11, S72-S73. [CrossRef]

59. Sanchez, B.; Robledo, M.; Biarnes, J.; Saez, M.E.; Volpini, V.; Benitez, J.; Navarro, E.; Ruiz, A.; Antinolo, G.; Borrego, S. High prevalence of the C634Y mutation in the RET proto-oncogene in MEN 2A families in Spain. J. Med. Genet. 1999, 36, 68-70.

60. Martinez-Criado, Y.; Fernandez, R.M.; Borrego, S.; Cabello, R.; Fernandez-Pineda, I. Genetic disorders of pediatric MEN2A patients in the south of Spain. Clin. Transl. Oncol. 2014, 16, 1018-1021. [CrossRef]

61. Wells, S.A., Jr.; Pacini, F.; Robinson, B.G.; Santoro, M. Multiple endocrine neoplasia type 2 and familial medullary thyroid carcinoma: An update. J. Clin. Endocrinol. Metab. 2013, 98, 3149-3164. [CrossRef]

62. Bolino, A.; Schuffenecker, I.; Luo, Y.; Seri, M.; Silengo, M.; Tocco, T.; Chabrier, G.; Houdent, C.; Murat, A.; Schlumberger, M.; et al. RET mutations in exons 13 and 14 of FMTC patients. Oncogene 1995, 10, 2415-2419.

63. Pasini, A.; Geneste, O.; Legrand, P.; Schlumberger, M.; Rossel, M.; Fournier, L.; Rudkin, B.B.; Schuffenecker, I.; Lenoir, G.M.; Billaud, M. Oncogenic activation of RET by two distinct FMTC mutations affecting the tyrosine kinase domain. Oncogene 1997, 15, 393-402. [CrossRef]

64. Kodama, Y.; Asai, N.; Kawai, K.; Jijiwa, M.; Murakumo, Y.; Ichihara, M.; Takahashi, M. The RET proto-oncogene: A molecular therapeutic target in thyroid cancer. Cancer Sci. 2005, 96, 143-148. [CrossRef]

65. Santoro, M.; Carlomagno, F. Central role of RET in thyroid cancer. Cold Spring Harb. Perspect. Biol. 2013, 5, a009233. [CrossRef]

66. Drosten, M.; Putzer, B.M. Mechanisms of Disease: Cancer targeting and the impact of oncogenic RET for medullary thyroid carcinoma therapy. Nat. Clin. Pract. Oncol. 2006, 3, 564-574. [CrossRef]

67. Ruiz, A.; Antinolo, G.; Fernandez, R.M.; Eng, C.; Marcos, I.; Borrego, S. Germline sequence variant S836S in the RET proto-oncogene is associated with low level predisposition to sporadic medullary thyroid carcinoma in the Spanish population. Clin. Endocrinol. 2001, 55, 399-402. [CrossRef]

68. Gimm, O.; Neuberg, D.S.; Marsh, D.J.; Dahia, P.L.; Hoang-Vu, C.; Raue, F.; Hinze, R.; Dralle, H.; Eng, C. Over-representation of a germline RET sequence variant in patients with sporadic medullary thyroid carcinoma and somatic RET codon 918 mutation. Oncogene 1999, 18, 1369-1373. [CrossRef]

69. Lesueur, F.; Cebrian, A.; Robledo, M.; Niccoli-Sire, P.; Svensson, K.A.; Pinson, S.; Leyland, J.; Whittaker, J.; Pharoah, P.D.; Ponder, B.A. Polymorphisms in RET and its coreceptors and ligands as genetic modifiers of multiple endocrine neoplasia type 2A. Cancer Res. 2006, 66, 1177-1180. [CrossRef]

70. Fernandez, R.M.; Pecina, A.; Antinolo, G.; Navarro, E.; Borrego, S. Analysis of RET polymorphisms and haplotypes in the context of sporadic medullary thyroid carcinoma. Thyroid 2006, 16, 411-417. [CrossRef]

71. Fernandez, R.M.; Robledo, M.; Antinolo, G.; Pecina, A.; Ruiz-Llorente, S.; Eng, C.; Borrego, S. The RET IVS1-126G $>$ T variant is strongly associated with the development of sporadic medullary thyroid cancer. Thyroid 2004, 14, 329-331. [CrossRef]

72. Fernandez, R.M.; Sanchez-Mejias, A.; Navarro, E.; Lopez-Alonso, M.; Antinolo, G.; Borrego, S. The RET functional variant $\mathrm{C} * 587 \mathrm{~T}>\mathrm{C}$ is not associated with susceptibility to sporadic medullary thyroid cancer. Thyroid 2009, 19, 1017-1018. [CrossRef]

73. Griseri, P.; Lantieri, F.; Puppo, F.; Bachetti, T.; Di Duca, M.; Ravazzolo, R.; Ceccherini, I. A common variant located in the $3^{\prime} \mathrm{UTR}$ of the RET gene is associated with protection from Hirschsprung disease. Hum. Mutat. 2007, 28, 168-176. [CrossRef]

74. Borrego, S.; Fernandez, R.M.; Dziema, H.; Japon, M.A.; Marcos, I.; Eng, C.; Antinolo, G. Evaluation of germline sequence variants of GFRA1, GFRA2, and GFRA3 genes in a cohort of Spanish patients with sporadic medullary thyroid cancer. Thyroid 2002, 12, 1017-1022. [CrossRef] 
75. Kunstman, J.W.; Juhlin, C.C.; Goh, G.; Brown, T.C.; Stenman, A.; Healy, J.M.; Rubinstein, J.C.; Choi, M.; Kiss, N.; Nelson-Williams, C.; et al. Characterization of the mutational landscape of anaplastic thyroid cancer via whole-exome sequencing. Hum. Mol. Genet. 2015, 24, 2318-2329. [CrossRef]

76. Xing, M.; Clark, D.; Guan, H.; Ji, M.; Dackiw, A.; Carson, K.A.; Kim, M.; Tufaro, A.; Ladenson, P.; Zeiger, M.; et al. BRAF mutation testing of thyroid fine-needle aspiration biopsy specimens for preoperative risk stratification in papillary thyroid cancer. J. Clin. Oncol. 2009, 27, 2977-2982. [CrossRef]

77. Dhillon, A.S.; Kolch, W. Oncogenic B-Raf mutations: Crystal clear at last. Cancer Cell 2004, 5, $303-304$. [CrossRef]

78. Mitsutake, N.; Miyagishi, M.; Mitsutake, S.; Akeno, N.; Mesa, C., Jr.; Knauf, J.A.; Zhang, L.; Taira, K.; Fagin, J.A. BRAF mediates RET/PTC-induced mitogen-activated protein kinase activation in thyroid cells: Functional support for requirement of the RET/PTC-RAS-BRAF pathway in papillary thyroid carcinogenesis. Endocrinology 2006, 147, 1014-1019. [CrossRef]

79. Wan, P.T.; Garnett, M.J.; Roe, S.M.; Lee, S.; Niculescu-Duvaz, D.; Good, V.M.; Jones, C.M.; Marshall, C.J.; Springer, C.J.; Barford, D.; et al. Mechanism of activation of the RAF-ERK signaling pathway by oncogenic mutations of B-RAF. Cell 2004, 116, 855-867. [CrossRef]

80. Liu, D.; Liu, Z.; Condouris, S.; Xing, M. BRAF V600E maintains proliferation, transformation, and tumorigenicity of BRAF-mutant papillary thyroid cancer cells. J. Clin. Endocrinol. Metab. 2007, 92, 2264-2271. [CrossRef]

81. Mitsutake, N.; Knauf, J.A.; Mitsutake, S.; Mesa, C., Jr.; Zhang, L.; Fagin, J.A. Conditional BRAFV600E expression induces DNA synthesis, apoptosis, dedifferentiation, and chromosomal instability in thyroid PCCL3 cells. Cancer Res. 2005, 65, 2465-2473. [CrossRef]

82. Di Cristofaro, J.; Marcy, M.; Vasko, V.; Sebag, F.; Fakhry, N.; Wynford-Thomas, D.; De Micco, C. Molecular genetic study comparing follicular variant versus classic papillary thyroid carcinomas: Association of N-ras mutation in codon 61 with follicular variant. Hum. Pathol. 2006, 37, 824-830. [CrossRef]

83. Esapa, C.T.; Johnson, S.J.; Kendall-Taylor, P.; Lennard, T.W.; Harris, P.E. Prevalence of Ras mutations in thyroid neoplasia. Clin. Endocrinol. 1999, 50, 529-535. [CrossRef]

84. Kondo, T.; Ezzat, S.; Asa, S.L. Pathogenetic mechanisms in thyroid follicular-cell neoplasia. Nat. Rev. Cancer 2006, 6, 292-306. [CrossRef]

85. Santarpia, L.; Myers, J.N.; Sherman, S.I.; Trimarchi, F.; Clayman, G.L.; El-Naggar, A.K. Genetic alterations in the RAS/RAF/mitogen-activated protein kinase and phosphatidylinositol 3-kinase/Akt signaling pathways in the follicular variant of papillary thyroid carcinoma. Cancer 2010, 116, 2974-2983. [CrossRef]

86. Vasko, V.V.; Gaudart, J.; Allasia, C.; Savchenko, V.; Di Cristofaro, J.; Saji, M.; Ringel, M.D.; De Micco, C. Thyroid follicular adenomas may display features of follicular carcinoma and follicular variant of papillary carcinoma. Eur. J. Endocrinol. 2004, 151, 779-786. [CrossRef]

87. Liu, R.; Xing, M. TERT promoter mutations in thyroid cancer. Endocr. Relat Cancer 2016, 23, R143. [CrossRef]

88. Zhang, Y.; Yu, J.; Grachtchouk, V.; Qin, T.; Lumeng, C.N.; Sartor, M.A.; Koenig, R.J. Genomic binding of PAX8-PPARG fusion protein regulates cancer-related pathways and alters the immune landscape of thyroid cancer. Oncotarget 2017, 8, 5761-5773. [CrossRef]

89. Molinaro, E.; Romei, C.; Biagini, A.; Sabini, E.; Agate, L.; Mazzeo, S.; Materazzi, G.; Sellari-Franceschini, S.; Ribechini, A.; Torregrossa, L.; et al. Anaplastic thyroid carcinoma: From clinicopathology to genetics and advanced therapies. Nat. Rev. Endocrinol. 2017, 13, 644-660. [CrossRef]

90. Manzella, L.; Stella, S.; Pennisi, M.S.; Tirro, E.; Massimino, M.; Romano, C.; Puma, A.; Tavarelli, M.; Vigneri, P. New Insights in Thyroid Cancer and p53 Family Proteins. Int. J. Mol. Sci. 2017, 18, 1325. [CrossRef]

91. Maliszewska, A.; Leandro-Garcia, L.J.; Castelblanco, E.; Macia, A.; de Cubas, A.; Gomez-Lopez, G.; Inglada-Perez, L.; Alvarez-Escola, C.; De la Vega, L.; Leton, R.; et al. Differential gene expression of medullary thyroid carcinoma reveals specific markers associated with genetic conditions. Am. J. Pathol. 2013, 182, 350-362. [CrossRef]

92. Smith, J.; Read, M.L.; Hoffman, J.; Brown, R.; Bradshaw, B.; Campbell, C.; Cole, T.; Navas, J.D.; Eatock, F.; Gundara, J.S.; et al. Germline ESR2 mutation predisposes to medullary thyroid carcinoma and causes up-regulation of RET expression. Hum. Mol. Genet. 2016, 25, 1836-1845. [CrossRef]

93. Ruiz-Ferrer, M.; Fernandez, R.M.; Navarro, E.; Antinolo, G.; Borrego, S. ESR2 Gene and Medullary Thyroid Carcinoma. Thyroid 2017, 27, 1456-1457. [CrossRef] 
94. Kelly, L.M.; Barila, G.; Liu, P.; Evdokimova, V.N.; Trivedi, S.; Panebianco, F.; Gandhi, M.; Carty, S.E.; Hodak, S.P.; Luo, J.; et al. Identification of the transforming STRN-ALK fusion as a potential therapeutic target in the aggressive forms of thyroid cancer. Proc. Natl. Acad. Sci. USA 2014, 111, 4233-4238. [CrossRef]

95. Bastos, A.U.; de Jesus, A.C.; Cerutti, J.M. ETV6-NTRK3 and STRN-ALK kinase fusions are recurrent events in papillary thyroid cancer of adult population. Eur. J. Endocrinol. 2018, 178, 83-91. [CrossRef]

96. Fernandez, L.P.; Lopez-Marquez, A.; Martinez, A.M.; Gomez-Lopez, G.; Santisteban, P. New insights into FoxE1 functions: Identification of direct FoxE1 targets in thyroid cells. PLoS ONE 2013, 8, e62849. [CrossRef]

97. Mendieta-Zeron, H.; Jimenez-Rosales, A.; Perez-Amado, C.J.; Jimenez-Morales, S. FOXE1 Mutation Screening in a Case with Cleft Lip, Hypothyroidism, and Thyroid Carcinoma: A New Syndrome? Case Rep. Genet. 2017, 2017, 6390545. [CrossRef]

98. Penna-Martinez, M.; Epp, F.; Kahles, H.; Ramos-Lopez, E.; Hinsch, N.; Hansmann, M.L.; Selkinski, I.; Grunwald, F.; Holzer, K.; Bechstein, W.O.; et al. FOXE1 association with differentiated thyroid cancer and its progression. Thyroid 2014, 24, 845-851. [CrossRef]

99. Eng, C.; Smith, D.P.; Mulligan, L.M.; Healey, C.S.; Zvelebil, M.J.; Stonehouse, T.J.; Ponder, M.A.; Jackson, C.E.; Waterfield, M.D.; Ponder, B.A. A novel point mutation in the tyrosine kinase domain of the RET proto-oncogene in sporadic medullary thyroid carcinoma and in a family with FMTC. Oncogene 1995, 10, 509-513.

100. Liaw, D.; Marsh, D.J.; Li, J.; Dahia, P.L.; Wang, S.I.; Zheng, Z.; Bose, S.; Call, K.M.; Tsou, H.C.; Peacocke, M.; et al. Germline mutations of the PTEN gene in Cowden disease, an inherited breast and thyroid cancer syndrome. Nat. Genet. 1997, 16, 64-67. [CrossRef]

101. Lozada, J.R.; Basili, T.; Pareja, F.; Alemar, B.; Paula, A.D.C.; Gularte-Merida, R.; Giri, D.D.; Querzoli, P.; Cserni, G.; Rakha, E.A.; et al. Solid papillary breast carcinomas resembling the tall cell variant of papillary thyroid neoplasms (solid papillary carcinomas with reverse polarity) harbour recurrent mutations affecting IDH2 and PIK3CA: A validation cohort. Histopathology 2018, 73, 339-344. [CrossRef]

102. Orloff, M.S.; He, X.; Peterson, C.; Chen, F.; Chen, J.L.; Mester, J.L.; Eng, C. Germline PIK3CA and AKT1 mutations in Cowden and Cowden-like syndromes. Am. J. Hum. Genet. 2013, 92, 76-80. [CrossRef]

103. Landa, I.; Ibrahimpasic, T.; Boucai, L.; Sinha, R.; Knauf, J.A.; Shah, R.H.; Dogan, S.; Ricarte-Filho, J.C.; Krishnamoorthy, G.P.; Xu, B.; et al. Genomic and transcriptomic hallmarks of poorly differentiated and anaplastic thyroid cancers. J. Clin. Invest. 2016, 126, 1052-1066. [CrossRef]

104. Marques, I.J.; Moura, M.M.; Cabrera, R.; Pinto, A.E.; Simoes-Pereira, J.; Santos, C.; Menezes, F.D.; Montezuma, D.; Henrique, R.; Rodrigues Teixeira, M.; et al. Identification of somatic TERT promoter mutations in familial nonmedullary thyroid carcinomas. Clin. Endocrinol. 2017, 87, 394-399. [CrossRef]

105. Borowczyk, M.; Szczepanek-Parulska, E.; Debicki, S.; Budny, B.; Verburg, F.A.; Filipowicz, D.; Wieckowska, B.; Janicka-Jedynska, M.; Gil, L.; Ziemnicka, K.; et al. Differences in Mutational Profile between Follicular Thyroid Carcinoma and Follicular Thyroid Adenoma Identified Using Next Generation Sequencing. Int. J. Mol. Sci. 2019, 20, 3126. [CrossRef]

106. Bonhomme, B.; Godbert, Y.; Perot, G.; Al Ghuzlan, A.; Bardet, S.; Belleannee, G.; Criniere, L.; Do Cao, C.; Fouilloux, G.; Guyetant, S.; et al. Molecular Pathology of Anaplastic Thyroid Carcinomas: A Retrospective Study of 144 Cases. Thyroid 2017, 27, 682-692. [CrossRef]

107. Gerber, T.S.; Schad, A.; Hartmann, N.; Springer, E.; Zechner, U.; Musholt, T.J. Targeted next-generation sequencing of cancer genes in poorly differentiated thyroid cancer. Endocr. Connect. 2018, 7, 47-55. [CrossRef]

108. Guha, T.; Malkin, D. Inherited TP53 Mutations and the Li-Fraumeni Syndrome. Cold Spring Harb. Perspect. Med. 2017, 7. [CrossRef]

109. Hincza, K.; Kowalik, A.; Kowalska, A. Current Knowledge of Germline Genetic Risk Factors for the Development of Non-Medullary Thyroid Cancer. Genes 2019, 10, 482. [CrossRef]

110. Sponziello, M.; Benvenuti, S.; Gentile, A.; Pecce, V.; Rosignolo, F.; Virzi, A.R.; Milan, M.; Comoglio, P.M.; Londin, E.; Fortina, P.; et al. Whole exome sequencing identifies a germline MET mutation in two siblings with hereditary wild-type RET medullary thyroid cancer. Hum. Mutat. 2018, 39, 371-377. [CrossRef]

111. Bae, J.S.; Kim, Y.; Jeon, S.; Kim, S.H.; Kim, T.J.; Lee, S.; Kim, M.H.; Lim, D.J.; Lee, Y.S.; Jung, C.K. Clinical utility of TERT promoter mutations and ALK rearrangement in thyroid cancer patients with a high prevalence of the BRAF V600E mutation. Diagn. Pathol. 2016, 11, 21. [CrossRef] 
112. Iwama, T.; Konishi, M.; Iijima, T.; Yoshinaga, K.; Tominaga, T.; Koike, M.; Miyaki, M. Somatic mutation of the APC gene in thyroid carcinoma associated with familial adenomatous polyposis. Jpn. J. Cancer Res. 1999, 90, 372-376. [CrossRef]

113. Lam, A.K.; Saremi, N. Cribriform-morular variant of papillary thyroid carcinoma: A distinctive type of thyroid cancer. Endocr. Relat. Cancer 2017, 24, R109-R121. [CrossRef]

114. Uchino, S.; Noguchi, S.; Yamashita, H.; Yamashita, H.; Watanabe, S.; Ogawa, T.; Tsuno, A.; Murakami, A.; Miyauchi, A. Mutational analysis of the APC gene in cribriform-morula variant of papillary thyroid carcinoma. World J. Surg. 2006, 30, 775-779. [CrossRef]

115. Xu, B.; Yoshimoto, K.; Miyauchi, A.; Kuma, S.; Mizusawa, N.; Hirokawa, M.; Sano, T. Cribriform-morular variant of papillary thyroid carcinoma: A pathological and molecular genetic study with evidence of frequent somatic mutations in exon 3 of the $\beta$-catenin gene. J. Pathol. 2003, 199, 58-67. [CrossRef]

116. Dobashi, Y.; Sugimura, H.; Sakamoto, A.; Mernyei, M.; Mori, M.; Oyama, T.; Machinami, R. Stepwise participation of $p 53$ gene mutation during dedifferentiation of human thyroid carcinomas. Diagn. Mol. Pathol. 1994, 3, 9-14. [CrossRef]

117. Garcia-Rostan, G.; Camp, R.L.; Herrero, A.; Carcangiu, M.L.; Rimm, D.L.; Tallini, G. $\beta$-catenin dysregulation in thyroid neoplasms: Down-regulation, aberrant nuclear expression, and CTNNB1 exon 3 mutations are markers for aggressive tumor phenotypes and poor prognosis. Am. J. Pathol. 2001, 158, 987-996. [CrossRef]

118. Liu,Z.; Hou, P.; Ji, M.; Guan, H.; Studeman, K.; Jensen, K.; Vasko, V.; El-Naggar, A.K.; Xing, M. Highly prevalent genetic alterations in receptor tyrosine kinases and phosphatidylinositol 3-kinase/akt and mitogen-activated protein kinase pathways in anaplastic and follicular thyroid cancers. J. Clin. Endocrinol. Metab. 2008, 93, 3106-3116. [CrossRef]

119. Leeman-Neill, R.J.; Kelly, L.M.; Liu, P.; Brenner, A.V.; Little, M.P.; Bogdanova, T.I.; Evdokimova, V.N.; Hatch, M.; Zurnadzy, L.Y.; Nikiforova, M.N.; et al. ETV6-NTRK3 is a common chromosomal rearrangement in radiation-associated thyroid cancer. Cancer 2014, 120, 799-807. [CrossRef]

120. Murugan, A.K.; Munirajan, A.K.; Alzahrani, A.S. Long noncoding RNAs: Emerging players in thyroid cancer pathogenesis. Endocr. Relat. Cancer 2018, 25, R59-R82. [CrossRef]

121. Nixon, A.M.; Provatopoulou, X.; Kalogera, E.; Zografos, G.N.; Gounaris, A. Circulating thyroid cancer biomarkers: Current limitations and future prospects. Clin. Endocrinol. 2017, 87, 117-126. [CrossRef]

122. Zembska, A.; Jawiarczyk-Przybylowska, A.; Wojtczak, B.; Bolanowski, M. MicroRNA Expression in the Progression and Aggressiveness of Papillary Thyroid Carcinoma. Anticancer Res. 2019, 39, 33-40. [CrossRef]

123. Zhang, R.; Hardin, H.; Chen, J.; Guo, Z.; Lloyd, R.V. Non-Coding RNAs in Thyroid Cancer. Endocr. Pathol. 2016, 27, 12-20. [CrossRef]

124. Luzon-Toro, B.; Bleda, M.; Navarro, E.; Garcia-Alonso, L.; Ruiz-Ferrer, M.; Medina, I.; Martin-Sanchez, M.; Gonzalez, C.Y.; Fernandez, R.M.; Torroglosa, A.; et al. Identification of epistatic interactions through genome-wide association studies in sporadic medullary and juvenile papillary thyroid carcinomas. BMC Med. Genom. 2015, 8, 83. [CrossRef] [PubMed]

125. Luzón-Toro, B.; Martos-Martínez, J.M.; Antiñolom, G.; Borrego, S. Identification of new long non-coding RNAs associated with medullary thyroid cancer. Oral Health Care 2019, 4, 1-3. [CrossRef]

126. Ramirez-Moya, J.; Santisteban, P. miRNA-Directed Regulation of the Main Signaling Pathways in Thyroid Cancer. Front. Endocrinol. 2019, 10, 430. [CrossRef] [PubMed]

127. Hutvagner, G.; McLachlan, J.; Pasquinelli, A.E.; Balint, E.; Tuschl, T.; Zamore, P.D. A cellular function for the RNA-interference enzyme Dicer in the maturation of the let-7 small temporal RNA. Science 2001, 293, 834-838. [CrossRef]

128. Hutvagner, G.; Zamore, P.D. A microRNA in a multiple-turnover RNAi enzyme complex. Science 2002, 297, 2056-2060. [CrossRef]

129. Wang, Y.; Stricker, H.M.; Gou, D.; Liu, L. MicroRNA: Past and present. Front. Biosci. 2007, 12, $2316-2329$. [CrossRef]

130. Lin, S.; Gregory, R.I. MicroRNA biogenesis pathways in cancer. Nat. Rev. Cancer 2015, 15, 321-333. [CrossRef]

131. Fuziwara, C.S.; Kimura, E.T. MicroRNAs in thyroid development, function and tumorigenesis. Mol. Cell Endocrinol. 2017, 456, 44-50. [CrossRef]

132. Riesco-Eizaguirre, G.; Santisteban, P. Endocrine tumours: Advances in the molecular pathogenesis of thyroid cancer: Lessons from the cancer genome. Eur. J. Endocrinol. 2016, 175, R203-R217. [CrossRef] 
133. Zhao, Y.; Liu, X.; Zhong, L.; He, M.; Chen, S.; Wang, T.; Ma, S. The combined use of miRNAs and mRNAs as biomarkers for the diagnosis of papillary thyroid carcinoma. Int. J. Mol. Med. 2015, 36, 1097-1103. [CrossRef]

134. De la Chapelle, A.; Jazdzewski, K. MicroRNAs in thyroid cancer. J. Clin. Endocrinol. Metab. 2011, 96, 3326-3336. [CrossRef]

135. Klinge, C.M. Non-coding RNAs: Long non-coding RNAs and microRNAs in endocrine-related cancers. Endocr. Relat. Cancer 2018, 25, R259-R282. [CrossRef]

136. Lima, C.R.; Gomes, C.C.; Santos, M.F. Role of microRNAs in endocrine cancer metastasis. Mol. Cell Endocrinol. 2017, 456, 62-75. [CrossRef]

137. Pallante, P.; Battista, S.; Pierantoni, G.M.; Fusco, A. Deregulation of microRNA expression in thyroid neoplasias. Nat. Rev. Endocrinol. 2014, 10, 88-101. [CrossRef]

138. Rehmsmeier, M.; Steffen, P.; Hochsmann, M.; Giegerich, R. Fast and effective prediction of microRNA/target duplexes. RNA 2004, 10, 1507-1517. [CrossRef]

139. Zhou, W.; Ye, X.L.; Xu, J.; Cao, M.G.; Fang, Z.Y.; Li, L.Y.; Guan, G.H.; Liu, Q.; Qian, Y.H.; Xie, D. The lncRNA H19 mediates breast cancer cell plasticity during EMT and MET plasticity by differentially sponging $\mathrm{miR}-200 \mathrm{~b} / \mathrm{c}$ and let-7b. Sci. Signal 2017, 10. [CrossRef]

140. Sui, F.; Ji, M.; Hou, P. Long non-coding RNAs in thyroid cancer: Biological functions and clinical significance. Mol. Cell Endocrinol. 2018, 469, 11-22. [CrossRef]

141. Matouk, I.J.; DeGroot, N.; Mezan, S.; Ayesh, S.; Abu-lail, R.; Hochberg, A.; Galun, E. The H19 non-coding RNA is essential for human tumor growth. PLoS ONE 2007, 2, e845. [CrossRef]

142. Liu, L.; Yang, J.; Zhu, X.; Li, D.; Lv, Z.; Zhang, X. Long noncoding RNA H19 competitively binds miR-17-5p to regulate YES1 expression in thyroid cancer. FEBS J. 2016, 283, 2326-2339. [CrossRef]

143. Schmidt, L.H.; Spieker, T.; Koschmieder, S.; Schaffers, S.; Humberg, J.; Jungen, D.; Bulk, E.; Hascher, A.; Wittmer, D.; Marra, A.; et al. The long noncoding MALAT-1 RNA indicates a poor prognosis in non-small cell lung cancer and induces migration and tumor growth. J. Thorac. Oncol. 2011, 6, 1984-1992. [CrossRef]

144. Zhang, R.; Hardin, H.; Huang, W.; Chen, J.; Asioli, S.; Righi, A.; Maletta, F.; Sapino, A.; Lloyd, R.V. MALAT1 Long Non-coding RNA Expression in Thyroid Tissues: Analysis by In Situ Hybridization and Real-Time PCR. Endocr. Pathol. 2017, 28, 7-12. [CrossRef]

145. Chu, Y.H.; Hardin, H.; Schneider, D.F.; Chen, H.; Lloyd, R.V. MicroRNA-21 and long non-coding RNA MALAT1 are overexpressed markers in medullary thyroid carcinoma. Exp. Mol. Pathol. 2017, 103, 229-236. [CrossRef]

146. Fan, M.; Li, X.; Jiang, W.; Huang, Y.; Li, J.; Wang, Z. A long non-coding RNA, PTCSC3, as a tumor suppressor and a target of miRNAs in thyroid cancer cells. Exp. Ther. Med. 2013, 5, 1143-1146. [CrossRef]

147. Du, Y.; Xia, W.; Zhang, J.; Wan, D.; Yang, Z.; Li, X. Comprehensive analysis of long noncoding RNA-mRNA co-expression patterns in thyroid cancer. Mol. Biosyst. 2017, 13, 2107-2115. [CrossRef]

148. Xiong, X.; Zhu, H.; Chen, X. Low expression of long noncoding RNA CASC2 indicates a poor prognosis and promotes tumorigenesis in thyroid carcinoma. Biomed. Pharmacother. 2017, 93, 391-397. [CrossRef]

149. Li, Z.; Gao, B.; Hao, S.; Tian, W.; Chen, Y.; Wang, L.; Zhang, X.; Luo, D. Knockdown of lncRNA-PANDAR suppresses the proliferation, cell cycle and promotes apoptosis in thyroid cancer cells. EXCLI J. 2017, 16, 354-362. [CrossRef]

150. Goedert, L.; Placa, J.R.; Fuziwara, C.S.; Machado, M.C.R.; Placa, D.R.; Almeida, P.P.; Sanches, T.P.; Santos, J.F.D.; Corveloni, A.C.; Pereira, I.E.G.; et al. Identification of Long Noncoding RNAs Deregulated in Papillary Thyroid Cancer and Correlated with BRAF(V600E) Mutation by Bioinformatics Integrative Analysis. Sci. Rep. 2017, 7, 1662. [CrossRef]

151. Pan, W.; Zhou, L.; Ge, M.; Zhang, B.; Yang, X.; Xiong, X.; Fu, G.; Zhang, J.; Nie, X.; Li, H.; et al. Whole exome sequencing identifies lncRNA GAS8-AS1 and LPAR4 as novel papillary thyroid carcinoma driver alternations. Hum. Mol. Genet. 2016, 25, 1875-1884. [CrossRef]

152. Zhang, D.; Liu, X.; Wei, B.; Qiao, G.; Jiang, T.; Chen, Z. Plasma lncRNA GAS8-AS1 as a Potential Biomarker of Papillary Thyroid Carcinoma in Chinese Patients. Int. J. Endocrinol. 2017, 2017, 2645904. [CrossRef]

153. Wang, Q.; Yang, H.; Wu, L.; Yao, J.; Meng, X.; Jiang, H.; Xiao, C.; Wu, F. Identification of Specific Long Non-Coding RNA Expression: Profile and Analysis of Association with Clinicopathologic Characteristics and BRAF Mutation in Papillary Thyroid Cancer. Thyroid 2016, 26, 1719-1732. [CrossRef]

154. Ma, B.; Liao, T.; Wen, D.; Dong, C.; Zhou, L.; Yang, S.; Wang, Y.; Ji, Q. Long intergenic non-coding RNA 271 is predictive of a poorer prognosis of papillary thyroid cancer. Sci. Rep. 2016, 6, 36973. [CrossRef] 
155. Bozgeyik, E.; Igci, Y.Z.; Sami Jacksi, M.F.; Arman, K.; Gurses, S.A.; Bozgeyik, I.; Pala, E.; Yumrutas, O.; Temiz, E.; Igci, M. A novel variable exonic region and differential expression of LINC00663 non-coding RNA in various cancer cell lines and normal human tissue samples. Tumour Biol. 2016, 37, 8791-8798. [CrossRef]

156. Lan, X.; Sun, W.; Zhang, P.; He, L.; Dong, W.; Wang, Z.; Liu, S.; Zhang, H. Downregulation of long noncoding RNA NONHSAT037832 in papillary thyroid carcinoma and its clinical significance. Tumour Biol. 2016, 37, 6117-6123. [CrossRef]

157. Wang, C.; Yan, G.; Zhang, Y.; Jia, X.; Bu, P. Long non-coding RNA MEG3 suppresses migration and invasion of thyroid carcinoma by targeting of Rac1. Neoplasma 2015, 62, 541-549. [CrossRef]

158. He, H.; Li, W.; Liyanarachchi, S.; Jendrzejewski, J.; Srinivas, M.; Davuluri, R.V.; Nagy, R.; de la Chapelle, A. Genetic predisposition to papillary thyroid carcinoma: Involvement of FOXE1, TSHR, and a novel lincRNA gene, PTCSC2. J. Clin. Endocrinol. Metab. 2015, 100, E164-E172. [CrossRef]

159. Jendrzejewski, J.; He, H.; Radomska, H.S.; Li, W.; Tomsic, J.; Liyanarachchi, S.; Davuluri, R.V.; Nagy, R.; de la Chapelle, A. The polymorphism rs 944289 predisposes to papillary thyroid carcinoma through a large intergenic noncoding RNA gene of tumor suppressor type. Proc. Natl. Acad. Sci. USA 2012, 109, 8646-8651. [CrossRef]

160. Jendrzejewski, J.; Liyanarachchi, S.; Nagy, R.; Senter, L.; Wakely, P.E.; Thomas, A.; Nabhan, F.; He, H.; Li, W.; Sworczak, K.; et al. Papillary Thyroid Carcinoma: Association Between Germline DNA Variant Markers and Clinical Parameters. Thyroid 2016, 26, 1276-1284. [CrossRef]

161. He, H.; Nagy, R.; Liyanarachchi, S.; Jiao, H.; Li, W.; Suster, S.; Kere, J.; de la Chapelle, A. A susceptibility locus for papillary thyroid carcinoma on chromosome 8q24. Cancer Res. 2009, 69, 625-631. [CrossRef]

162. Yoon, H.; He, H.; Nagy, R.; Davuluri, R.; Suster, S.; Schoenberg, D.; Pellegata, N.; Chapelle Ade, L. Identification of a novel noncoding RNA gene, NAMA, that is downregulated in papillary thyroid carcinoma with BRAF mutation and associated with growth arrest. Int. J. Cancer 2007, 121, 767-775. [CrossRef]

163. Zheng, H.; Wang, M.; Jiang, L.; Chu, H.; Hu, J.; Ning, J.; Li, B.; Wang, D.; Xu, J. BRAF-Activated Long Noncoding RNA Modulates Papillary Thyroid Carcinoma Cell Proliferation through Regulating Thyroid Stimulating Hormone Receptor. Cancer Res. Treat. 2016, 48, 698-707. [CrossRef]

164. Xia, S.; Wang, C.; Ni, X.; Ni, Z.; Dong, Y.; Zhan, W. NONHSAT076754 aids ultrasonography in predicting lymph node metastasis and promotes migration and invasion of papillary thyroid cancer cells. Oncotarget 2017, 8, 2293-2306. [CrossRef] [PubMed]

165. Li, Q.; Shen, W.; Li, X.; Zhang, L.; Jin, X. The lncRNA n340790 accelerates carcinogenesis of thyroid cancer by regulating miR-1254. Am. J. Transl. Res. 2017, 9, 2181-2194. [PubMed]

166. Zhang, Y.; Yu, S.; Jiang, L.; Wang, X.; Song, X. HOTAIR is a promising novel biomarker in patients with thyroid cancer. Exp. Ther. Med. 2017, 13, 2274-2278. [CrossRef] [PubMed]

167. Li, H.M.; Yang, H.; Wen, D.Y.; Luo, Y.H.; Liang, C.Y.; Pan, D.H.; Ma, W.; Chen, G.; He, Y.; Chen, J.Q. Overexpression of LncRNA HOTAIR is Associated with Poor Prognosis in Thyroid Carcinoma: A Study Based on TCGA and GEO Data. Horm. Metab. Res. 2017, 49, 388-399. [CrossRef] [PubMed]

168. Li, J.H.; Zhang, S.Q.; Qiu, X.G.; Zhang, S.J.; Zheng, S.H.; Zhang, D.H. Long non-coding RNA NEAT1 promotes malignant progression of thyroid carcinoma by regulating miRNA-214. Int. J. Oncol. 2017, 50, 708-716. [CrossRef]

169. Li, T.; Yang, X.D.; Ye, C.X.; Shen, Z.L.; Yang, Y.; Wang, B.; Guo, P.; Gao, Z.D.; Ye, Y.J.; Jiang, K.W.; et al. Long noncoding RNA HIT000218960 promotes papillary thyroid cancer oncogenesis and tumor progression by upregulating the expression of high mobility group AT-hook 2 (HMGA2) gene. Cell Cycle 2017, 16, $224-231$. [CrossRef]

170. Sun, W.; Lan, X.; Wang, Z.; Dong, W.; He, L.; Zhang, T.; Zhang, H. Overexpression of long non-coding RNA NR_036575.1 contributes to the proliferation and migration of papillary thyroid cancer. Med. Oncol. 2016, 33, 102. [CrossRef]

171. Zhao, J.J.; Hao, S.; Wang, L.L.; Hu, C.Y.; Zhang, S.; Guo, L.J.; Zhang, G.; Gao, B.; Jiang, Y.; Tian, W.G.; et al. Long non-coding RNA ANRIL promotes the invasion and metastasis of thyroid cancer cells through TGF- $\beta /$ Smad signaling pathway. Oncotarget 2016, 7, 57903-57918. [CrossRef]

172. Liyanarachchi, S.; Li, W.; Yan, P.; Bundschuh, R.; Brock, P.; Senter, L.; Ringel, M.D.; de la Chapelle, A.; He, H. Genome-Wide Expression Screening Discloses Long Noncoding RNAs Involved in Thyroid Carcinogenesis. J. Clin. Endocrinol. Metab. 2016, 101, 4005-4013. [CrossRef] 
173. Kim, D.; Lee, W.K.; Jeong, S.; Seol, M.Y.; Kim, H.; Kim, K.S.; Lee, E.J.; Lee, J.; Jo, Y.S. Upregulation of long noncoding RNA LOC100507661 promotes tumor aggressiveness in thyroid cancer. Mol. Cell Endocrinol. 2016, 431, 36-45. [CrossRef]

174. Jeong, S.; Lee, J.; Kim, D.; Seol, M.Y.; Lee, W.K.; Jeong, J.J.; Nam, K.H.; Jung, S.G.; Shin, D.Y.; Lee, E.J.; et al. Relationship of Focally Amplified Long Noncoding on Chromosome 1 (FAL1) lncRNA with E2F Transcription Factors in Thyroid Cancer. Medicine 2016, 95, e2592. [CrossRef] [PubMed]

175. Xu, B.; Shao, Q.; Xie, K.; Zhang, Y.; Dong, T.; Xia, Y.; Tang, W. The Long Non-Coding RNA ENST00000537266 and ENST00000426615 Influence Papillary Thyroid Cancer Cell Proliferation and Motility. Cell Physiol. Biochem. 2016, 38, 368-378. [CrossRef] [PubMed]

176. Zhou, Q.; Chen, J.; Feng, J.; Wang, J. Long noncoding RNA PVT1 modulates thyroid cancer cell proliferation by recruiting EZH2 and regulating thyroid-stimulating hormone receptor (TSHR). Tumour Biol. 2016, 37, 3105-3113. [CrossRef] [PubMed]

177. Wang, Y.; Guo, Q.; Zhao, Y.; Chen, J.; Wang, S.; Hu, J.; Sun, Y. BRAF-activated long non-coding RNA contributes to cell proliferation and activates autophagy in papillary thyroid carcinoma. Oncol. Lett. 2014, 8, 1947-1952. [CrossRef] [PubMed]

178. Hu, Q.; Tai, S.; Wang, J. Oncogenicity of lncRNA FOXD2-AS1 and its molecular mechanisms in human cancers. Pathol. Res. Pract. 2019, 215, 843-848. [CrossRef] [PubMed]

179. Ji, D.; Zhong, X.; Jiang, X.; Leng, K.; Xu, Y.; Li, Z.; Huang, L.; Li, J.; Cui, Y. The role of long non-coding RNA AFAP1-AS1 in human malignant tumors. Pathol. Res. Pract. 2018, 214, 1524-1531. [CrossRef] [PubMed]

180. Wang, W.; Xia, S.; Zhan, W. The Long Non-Coding RNA ENST00000489676 Influences Papillary Thyroid Cancer Cell Proliferation and Invasion through Regulating MiR-922. J. Cancer 2019, 10, 5434-5446. [CrossRef]

181. Luzon-Toro, B.; Fernandez, R.M.; Martos-Martinez, J.M.; Rubio-Manzanares-Dorado, M.; Antinolo, G.; Borrego, S. LncRNA LUCAT1 as a novel prognostic biomarker for patients with papillary thyroid cancer. Sci. Rep. 2019, 9, 14374. [CrossRef]

182. Peng, N.; Shi, L.; Zhang, Q.; Hu, Y.; Wang, N.; Ye, H. Microarray profiling of circular RNAs in human papillary thyroid carcinoma. PLoS ONE 2017, 12, e0170287. [CrossRef]

183. Chen, S.; Zhang, L.; Su, Y.; Zhang, X. Screening potential biomarkers for colorectal cancer based on circular RNA chips. Oncol. Rep. 2018, 39, 2499-2512. [CrossRef]

184. Hang, D.; Zhou, J.; Qin, N.; Zhou, W.; Ma, H.; Jin, G.; Hu, Z.; Dai, J.; Shen, H. A novel plasma circular RNA circFARSA is a potential biomarker for non-small cell lung cancer. Cancer Med. 2018, 7, 2783-2791. [CrossRef] [PubMed]

185. Liu, X.; Liu, B.; Zhou, M.; Fan, F.; Yu, M.; Gao, C.; Lu, Y.; Luo, Y. Circular RNA HIPK3 regulates human lens epithelial cells proliferation and apoptosis by targeting the miR-193a/CRYAA axis. Biochem. Biophys. Res. Commun. 2018, 503, 2277-2285. [CrossRef] [PubMed]

186. Meng, S.; Zhou, H.; Feng, Z.; Xu, Z.; Tang, Y.; Li, P.; Wu, M. CircRNA: Functions and properties of a novel potential biomarker for cancer. Mol. Cancer 2017, 16, 94. [CrossRef] [PubMed]

187. Chen, B.; Huang, S. Circular RNA: An emerging non-coding RNA as a regulator and biomarker in cancer. Cancer Lett. 2018, 418, 41-50. [CrossRef] [PubMed]

188. Dragomir, M.; Calin, G.A. Circular RNAs in Cancer-Lessons Learned From microRNAs. Front. Oncol. 2018, 8, 179. [CrossRef] [PubMed]

189. Li, J.; Li, Q.; Chen, L.; Gao, Y.; Li, J. Expression profile of circular RNAs in infantile hemangioma detected by RNA-Seq. Medicine 2018, 97, e10882. [CrossRef] [PubMed]

190. Fan, C.M.; Wang, J.P.; Tang, Y.Y.; Zhao, J.; He, S.Y.; Xiong, F.; Guo, C.; Xiang, B.; Zhou, M.; Li, X.L.; et al. circMAN1A2 could serve as a novel serum biomarker for malignant tumors. Cancer Sci. 2019. [CrossRef]

191. Liu, W.; Zhao, J.; Jin, M.; Zhou, M. circRAPGEF5 Contributes to Papillary Thyroid Proliferation and Metastatis by Regulation miR-198/FGFR1. Mol. Ther. Nucl. Acids 2019, 14, 609-616. [CrossRef]

192. Wang, H.; Yan, X.; Zhang, H.; Zhan, X. CircRNA circ_0067934 Overexpression Correlates with Poor Prognosis and Promotes Thyroid Carcinoma Progression. Med. Sci. Monit. 2019, 25, 1342-1349. [CrossRef] 
193. Pan, Y.; Xu, T.; Liu, Y.; Li, W.; Zhang, W. Upregulated circular RNA circ_0025033 promotes papillary thyroid cancer cell proliferation and invasion via sponging miR-1231 and miR-1304. Biochem. Biophys. Res. Commun. 2019, 510, 334-338. [CrossRef]

194. Zhou, G.K.; Zhang, G.Y.; Yuan, Z.N.; Pei, R.; Liu, D.M. Has_circ_0008274 promotes cell proliferation and invasion involving AMPK/mTOR signaling pathway in papillary thyroid carcinoma. Eur. Rev. Med. Pharmacol. Sci. 2018, 22, 8772-8780. [CrossRef] [PubMed]

195. Tan, A.; Li, Q.; Chen, L. CircZFR promotes hepatocellular carcinoma progression through regulating miR-3619-5p/CTNNB1 axis and activating Wnt/ $\beta$-catenin pathway. Arch. Biochem. Biophys. 2019, 661, 196-202. [CrossRef]

196. Bi, W.; Huang, J.; Nie, C.; Liu, B.; He, G.; Han, J.; Pang, R.; Ding, Z.; Xu, J.; Zhang, J. CircRNA circRNA_102171 promotes papillary thyroid cancer progression through modulating CTNNBIP1-dependent activation of $\beta$-catenin pathway. J. Exp. Clin. Cancer Res. 2018, 37, 275. [CrossRef] [PubMed]

197. Li, X.; Tian, Y.; Hu, Y.; Yang, Z.; Zhang, L.; Luo, J. CircNUP214 sponges miR-145 to promote the expression of ZEB2 in thyroid cancer cells. Biochem. Biophys. Res. Commun. 2018, 507, 168-172. [CrossRef] [PubMed]

198. Wang, M.; Chen, B.; Ru, Z.; Cong, L. CircRNA circ-ITCH suppresses papillary thyroid cancer progression through miR-22-3p/CBL/ $\beta$-catenin pathway. Biochem. Biophys. Res. Commun. 2018, 504, 283-288. [CrossRef] [PubMed]

199. Jin, X.; Wang, Z.; Pang, W.; Zhou, J.; Liang, Y.; Yang, J.; Yang, L.; Zhang, Q. Upregulated hsa_circ_0004458 Contributes to Progression of Papillary Thyroid Carcinoma by Inhibition of miR-885-5p and Activation of RAC1. Med. Sci. Monit. 2018, 24, 5488-5500. [CrossRef]

200. Lan, X.; Xu, J.; Chen, C.; Zheng, C.; Wang, J.; Cao, J.; Zhu, X.; Ge, M. The Landscape of Circular RNA Expression Profiles in Papillary Thyroid Carcinoma Based on RNA Sequencing. Cell Physiol. Biochem. 2018, 47, 1122-1132. [CrossRef]

201. Wei, H.; Pan, L.; Tao, D.; Li, R. Circular RNA circZFR contributes to papillary thyroid cancer cell proliferation and invasion by sponging miR-1261 and facilitating C8orf4 expression. Biochem. Biophys. Res. Commun. 2018, 503, 56-61. [CrossRef]

202. Lan, X.; Cao, J.; Xu, J.; Chen, C.; Zheng, C.; Wang, J.; Zhu, X.; Zhu, X.; Ge, M. Decreased expression of hsa_circ_0137287 predicts aggressive clinicopathologic characteristics in papillary thyroid carcinoma. J. Clin. Lab. Anal. 2018, 32, e22573. [CrossRef]

203. Yao, Y.; Chen, X.; Yang, H.; Chen, W.; Qian, Y.; Yan, Z.; Liao, T.; Yao, W.; Wu, W.; Yu, T.; et al. Hsa_circ_0058124 promotes papillary thyroid cancer tumorigenesis and invasiveness through the NOTCH3/GATAD2A axis. J. Exp. Clin. Cancer Res. 2019, 38, 318. [CrossRef]

204. Liao, T.; Qu, N.; Shi, R.L.; Guo, K.; Ma, B.; Cao, Y.M.; Xiang, J.; Lu, Z.W.; Zhu, Y.X.; Li, D.S.; et al. BRAF-activated LncRNA functions as a tumor suppressor in papillary thyroid cancer. Oncotarget 2017, 8 , 238-247. [CrossRef] [PubMed]

205. Hyman, D.M.; Solit, D.B.; Arcila, M.E.; Cheng, D.T.; Sabbatini, P.; Baselga, J.; Berger, M.F.; Ladanyi, M. Precision medicine at Memorial Sloan Kettering Cancer Center: Clinical next-generation sequencing enabling next-generation targeted therapy trials. Drug Discov. Today 2015, 20, 1422-1428. [CrossRef] [PubMed]

206. Ibrahimpasic, T.; Ghossein, R.; Shah, J.P.; Ganly, I. Poorly Differentiated Carcinoma of the Thyroid Gland: Current Status and Future Prospects. Thyroid 2019, 29, 311-321. [CrossRef] [PubMed]

207. Mitchell, J.; Yip, L. Decision Making in Indeterminate Thyroid Nodules and the Role of Molecular Testing. Surg. Clin. North. Am. 2019, 99, 587-598. [CrossRef] [PubMed]

208. Cha, Y.J.; Koo, J.S. Next-generation sequencing in thyroid cancer. J. Transl. Med. 2016, 14, 322. [CrossRef] [PubMed]

209. Ho, A.L.; Grewal, R.K.; Leboeuf, R.; Sherman, E.J.; Pfister, D.G.; Deandreis, D.; Pentlow, K.S.; Zanzonico, P.B.; Haque, S.; Gavane, S.; et al. Selumetinib-enhanced radioiodine uptake in advanced thyroid cancer. N. Engl. J. Med. 2013, 368, 623-632. [CrossRef] 
210. Alexander, E.K.; Kennedy, G.C.; Baloch, Z.W.; Cibas, E.S.; Chudova, D.; Diggans, J.; Friedman, L.; Kloos, R.T.; LiVolsi, V.A.; Mandel, S.J.; et al. Preoperative diagnosis of benign thyroid nodules with indeterminate cytology. N. Engl. J. Med. 2012, 367, 705-715. [CrossRef]

211. Nikiforov, Y.E.; Ohori, N.P.; Hodak, S.P.; Carty, S.E.; LeBeau, S.O.; Ferris, R.L.; Yip, L.; Seethala, R.R.; Tublin, M.E.; Stang, M.T.; et al. Impact of mutational testing on the diagnosis and management of patients with cytologically indeterminate thyroid nodules: A prospective analysis of 1056 FNA samples. J. Clin. Endocrinol. Metab. 2011, 96, 3390-3397. [CrossRef]

(C) 2019 by the authors. Licensee MDPI, Basel, Switzerland. This article is an open access article distributed under the terms and conditions of the Creative Commons Attribution (CC BY) license (http://creativecommons.org/licenses/by/4.0/). 